\title{
Short-term velocity variations at three rock glaciers and their relationship with meteorological conditions
}

\author{
V. Wirz ${ }^{1}$, S. Gruber ${ }^{2}$, R. S. Purves ${ }^{1}$, J. Beutel ${ }^{3}$, I. Gärtner-Roer ${ }^{1}$, S. Gubler ${ }^{4}$, and A. Vieli ${ }^{1}$ \\ ${ }^{1}$ Department of Geography, University of Zurich, Zurich, Switzerland \\ ${ }^{2}$ Department of Geography and Environmental Studies, Carleton University, Ottawa, Canada \\ ${ }^{3}$ Computer Engineering and Networks Laboratory, ETH, Zurich, Switzerland \\ ${ }^{4}$ Federal Office of Meteorology and Climatology MeteoSwiss, Zurich, Switzerland \\ Correspondence to: V. Wirz (vanessa.wirz@geo.uzh.ch)
}

Received: 30 March 2015 - Published in Earth Surf. Dynam. Discuss.: 28 May 2015

Revised: 1 December 2015 - Accepted: 23 December 2015 - Published: 25 January 2016

\begin{abstract}
In recent years, strong variations in the speed of rock glaciers have been detected, raising questions about their stability under changing climatic conditions. In this study, we present continuous time series of surface velocities over 3 years of six GPS stations located on three rock glaciers in Switzerland. Intra-annual velocity variations are analysed in relation to local meteorological factors, such as precipitation, snow(melt), and air and ground surface temperatures. The main focus of this study lies on the abrupt velocity peaks, which have been detected at two steep and fast-moving rock glacier tongues $\left(\geq 5 \mathrm{ma}^{-1}\right)$, and relationships to external meteorological forcing are statistically tested.

The continuous measurements with high temporal resolution allowed us to detect short-term velocity peaks, which occur outside cold winter conditions, at these two rock glacier tongues. Our measurements further revealed that all rock glaciers experience clear intra-annual variations in movement in which the timing and the amplitude is reasonably similar in individual years. The seasonal decrease in velocity was typically smooth, starting 1-3 months after the seasonal decrease in temperatures, and was stronger in years with colder temperatures in mid winter. Seasonal acceleration was mostly abrupt and rapid compared to the winter deceleration, always starting during the zero curtain period. We found a statistically significant relationship between the occurrence of shortterm velocity peaks and water input from heavy precipitation or snowmelt, while no velocity peak could be attributed solely to high temperatures. The findings of this study further suggest that, in addition to the shortterm velocity peaks, the seasonal acceleration is also influenced by water infiltration, causing thermal advection and an increase in pore water pressure. In contrast, the amount of deceleration in winter seems to be mainly controlled by winter temperatures.
\end{abstract}

\section{Introduction and related work}

Rock glaciers are a widespread landform in alpine permafrost terrain related to the creep of frozen debris or sediment. They shape and alter the landscape and contribute to the transport of sediment. In recent years, strong variations in the behaviour of rock glaciers have been detected, with a general trend towards increasing velocities over the past decade (see, e.g., Delaloye et al., 2008a), raising questions about the glaciers' stability in a changing climate.
We define rock glaciers by morphology, irrespective of their genesis, as lobate or tongue-shaped debris-ice mixtures, frequently with steep sides and snouts and longitudinal and/or transverse ridges and furrows, that are slowly creeping downslope (cf. Vitek and Giardino, 1987). Ice within rock glaciers may include buried surface ice (including glacier ice; see, e.g., Potter, 1972) or ice formed in situ (see, e.g., Wahrhaftig and Cox, 1959; Humlum et al., 2007). Rock glaciers with periglacial origins typically have an ice content of 50 
90\% (Potter, 1972; Barsch, 1977; Haeberli et al., 1998). In addition, the permafrost body is mostly permeable and air voids and liquid water can occur throughout the rock glacier body (Johnson and Nickling, 1979; Vonder Mühll, 1992; Wagner, 1992; Arenson et al., 2002; Buchli et al., 2013).

Horizontal displacements of alpine rock glaciers typically range between several centimetres to around $1 \mathrm{~m}$ per year (Haeberli et al., 2006), and maximum velocities occur along the central flow line and decrease towards the margins (see, e.g., Barsch, 1992; Haeberli, 1985; Roer et al., 2005).

In areas of compressive flow, surface structures such as transverse ridges and furrows are typical. However, related variations in flow speed are very small (Kääb et al., 2003; Kääb and Weber, 2004) and these surface structures are advected downstream with the speed of the rock glacier body (Kääb and Weber, 2004).

Typically, rock glacier flow velocities correlate with slope angle (Francou and Reynaud, 1992; Sloan and Dyke, 1998; Konrad et al., 1999). Movement observed at the rock glacier surface is in general due to deformation of the frozen rock glacier material; however, the magnitude of deformation is not necessarily uniform with depth (Fig. 1). The few existing studies on borehole-deformation measurements in rock glaciers all show that within the permafrost body, thin layers with distinctly different rheological properties (e.g. lower viscosity) exist, in which $50-97 \%$ of the horizontal deformation occurs (Wagner, 1992; Haeberli et al., 1998; Hoelzle et al., 1998; Arenson et al., 2002; Buchli et al., 2013, Fig. 1). Typically, no internal deformation occurs below such shear horizons, and only limited internal deformation occurs above them. Hence, surface displacement measurements appear to be a good approximation of the slope movement of the entire rock glacier.

In recent years an increasing number of studies have detected temporal variations in rock glacier movement distinguishing three timescales: decennial, interannual, and intraannual (Delaloye et al., 2010).

In the Alps, long-term variations have been observed since the 1950s, with significant acceleration in the 1980s (see, e.g., Roer et al., 2005; Kääb et al., 2007; Kaufmann and Ladstädter, 2007; Lugon et al., 2008; Delaloye et al., 2008a) which has been related to longer-term variations in climatic conditions. The majority of studies are, however, on the interannual (year-to-year) timescale (e.g. Krummenacher et al., 2008; Perruchoud and Delaloye, 2007). Annually repeated measurements at 16 rock glaciers across the European Alps, suggest that most have strong, generally synchronized, interannual velocity variations (Delaloye et al., 2008a, 2010; PERMOS, 2013), which have been related to external climatic factors. The proposed main mechanism linking long-term and interannual variations to climate is through heat conduction and the related change in temperature and hence deformation of the rock glacier body (see, e.g., Hoelzle et al., 1998; Delaloye et al., 2008a, 2010; Schoeneich et al., 2015). Furthermore, en-

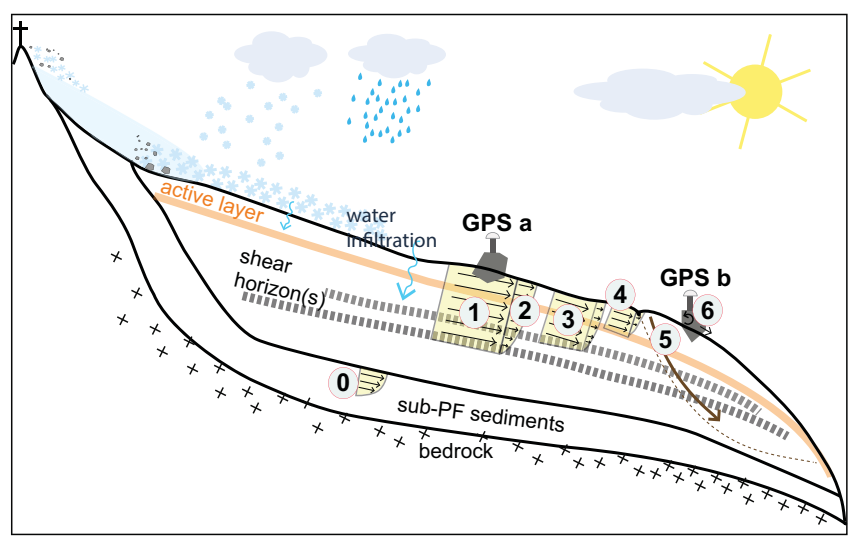

Figure 1. Schematic profile of a rock glacier. The observed movement at the surface might result from movement at different depths of the rock glacier (Roer et al., 2008): (0) deformation of subpermafrost sediments (Roer et al., 2008); (1) displacement within main shear horizon (see, e.g., Arenson et al., 2002); (2) (a little) internal deformation above shear horizon (see, e.g., Arenson et al., 2002); (3) displacement within additional shear horizon(s) (see, e.g., Delaloye et al., 2013); (4) displacement at base or within the active layer (AL) (see, e.g., Buchli et al., 2013); (5) displacement due to rotational slide (see, e.g., Roer et al., 2008); and/or (6) displacement or rotation of boulder at surface (Lambiel and Delaloye, 2004). Thick dashed lines within the rock glacier body indicate potential shear horizons.

hanced pore water pressure caused by snow meltwater infiltration has also been suggested as a potentially influential factor for interannual variations in rock glacier movement (Ikeda et al., 2008; Krainer and He, 2006; Delaloye et al., 2010).

Observations of short-term, intra-annual variations in velocities, which are the main focus of this study, are less common, mainly because of limitations in measurement techniques. Most studies on these timescales are either based on measurements with low temporal resolutions ( $\sim 1-4$ months, e.g. Haeberli, 1985; Kääb et al., 2003; Roer, 2005; Perruchoud and Delaloye, 2007; Krummenacher et al., 2008) or had relatively short total observation periods typically of a few months (Roer, 2005; Krainer and He, 2006; Buchli et al., 2013, Table 1). An overview of previous studies on intra-annual variability in rock glacier movements and the related timescales is given in Table 1. For various rock glaciers, seasonal variations in velocity up to $50 \%$ of the mean annual velocity were observed (see, e.g., Haeberli, 1985; Hausmann et al., 2007; Perruchoud and Delaloye, 2007), but the magnitude often varied significantly from year to year (Delaloye et al., 2010). Such seasonal fluctuations occur mostly at the same time of the year (Delaloye et al., 2010), with highest velocities in autumn or late summer and lowest velocities in winter (Kääb et al., 2005; Perruchoud and Delaloye, 2007; Buchli et al., 2013). 
Table 1. Overview of previous studies on the intra-annual variability in rock glacier movement found in literature. For each study (if available) the following information is listed: name and location of investigated rock glacier(s) (location), the number of measurement points $(N)$, the surveying technology (technology), the observation period (period), and the temporal resolution (resolution). In addition, it is indicated for each study whether the following observations have been made (yes: observed; no: not observed; ?: no statement): a seasonal cycle of the movement (seasonal cycle), a smoother seasonal deceleration than acceleration (smoother deceleration), a seasonal acceleration beginning during the snowmelt period (acceleration during snowmelt).

\begin{tabular}{|c|c|c|c|c|c|c|c|c|}
\hline Location & $N$ & Technology & Period & Resolution & $\begin{array}{l}\text { Seasonal } \\
\text { cycle }\end{array}$ & $\begin{array}{l}\text { Smoother } \\
\text { deceleration }\end{array}$ & $\begin{array}{l}\text { Acceleration } \\
\text { during snowmelt }\end{array}$ & Reference \\
\hline $\begin{array}{l}\text { Murtel/Muragl } \\
\text { (Grison, Switzerland) }\end{array}$ & $45 / 14$ & photogrammetry & $1971-1973$ & & yes & ? & ? & $\begin{array}{l}\text { Barsch and Hell (1975) } \\
\text { Wagner (1994) }\end{array}$ \\
\hline $\begin{array}{l}\text { Gruben } \\
\text { (Valais, Switzerland) }\end{array}$ & 8 & $\begin{array}{l}\text { electro-optical distance } \\
\text { measurement }\end{array}$ & $\begin{array}{l}\text { August 1979-August } \\
1982\end{array}$ & $\sim 3$ months & yes & ? & $?$ & Haeberli (1985) \\
\hline $\begin{array}{l}\text { Furggentaelti } \\
\text { (Bernese Alps, } \\
\text { Switzerland) }\end{array}$ & 32 & tachymetry & $\begin{array}{l}\text { autumn } 1998-1999 \\
\text { (1 year) }\end{array}$ & monthly & yes & yes & yes & $\begin{array}{l}\text { Mihajlovic et al. (2003) } \\
\text { Krummenacher et al. (2008) }\end{array}$ \\
\hline $\begin{array}{l}\text { Muragl } \\
\text { (Grison, Switzerland) }\end{array}$ & 20 & total station & 1998-2001 & $\sim 4$ months & yes & no & no & $\begin{array}{l}\text { Kääb et al. (2003) } \\
\text { Kääb et al. (2005) }\end{array}$ \\
\hline $\begin{array}{l}\text { Muragl } \\
\text { (Grison, Switzerland) }\end{array}$ & 2 & $\begin{array}{l}\text { borehole } \\
\text { inclinometer }\end{array}$ & 1999-2000 & $\sim$ monthly & yes & no & no & Arenson et al. (2002) \\
\hline $\begin{array}{l}\text { Reichenkar } \\
\text { (Stubai Alps, Austria) }\end{array}$ & 3 & GPS & $\begin{array}{l}\text { July-September } 2003 \\
\text { and } \\
\text { June-October } 2002\end{array}$ & $10 \mathrm{~s}(87 \mathrm{~d})$ & no & no & no & Krainer and $\mathrm{He}$ (2006) \\
\hline $\begin{array}{l}\text { Huhh1 in Hungerlitälli } \\
\text { (Valais, Switzerland) }\end{array}$ & 25 & $\begin{array}{l}\text { terrestrial geodetic } \\
\text { survey }\end{array}$ & July-August 2003 & 36 days & yes & $?$ & ? & Roer (2005) \\
\hline $\begin{array}{l}\text { Oelgrube } \\
\text { (Stubai Alps, Austria) }\end{array}$ & 21 & GPS & July-September 2003 & 55 days & yes & ? & $?$ & $\begin{array}{l}\text { Krainer and He (2006) } \\
\text { Hausmann et al. (2007) }\end{array}$ \\
\hline $\begin{array}{l}\text { Tsarmine } \\
\text { (Valais, Switzerland) }\end{array}$ & & GPS & $\begin{array}{l}\text { October 2004- } \\
\text { August } 2005\end{array}$ & $\geq 8$ months & yes & $?$ & $?$ & $\begin{array}{l}\text { Lambiel and Delaloye (2004) } \\
\text { Lambiel et al. (2005) }\end{array}$ \\
\hline $\begin{array}{l}\text { Becs-de-Bosson } \\
\text { (Valais, Switzerland) }\end{array}$ & $6\left(85^{1}\right)$ & GPS & 2004-2006 & $30-60$ days & yes & yes & yes & $\begin{array}{l}\text { Perruchoud and Delaloye (2007) } \\
\text { Delaloye et al. (2010) }\end{array}$ \\
\hline $\begin{array}{l}\text { Mount Gibbs } \\
\text { (Sierra Nevada, USA) }\end{array}$ & 1 & InSAR & April 2007-May 2008 & 48-138 days & yes & $?$ & $?$ & Liu et al. (2013) \\
\hline $\begin{array}{l}\text { Furggwanghorn } \\
\text { (Valais, Switzerland) }\end{array}$ & 1 & $\begin{array}{l}\text { borehole } \\
\text { inclinometer }\end{array}$ & $\begin{array}{l}\text { October 2010-May } \\
2011\end{array}$ & daily & yes & yes & yes & Buchli et al. (2013) \\
\hline $\begin{array}{l}\text { Büz North } \\
\text { (Grison, Switzerland) }\end{array}$ & 1 & $\begin{array}{l}\text { borehole } \\
\text { inclinometer }\end{array}$ & $2000-2003 / 05$ & $3 \mathrm{~h}$ & yes & yes & yes & Ikeda et al. (2008) \\
\hline
\end{tabular}

Typically, such seasonal velocity fluctuations have been observed to lag behind ground surface temperature (GST) by a few weeks to months (Kääb, 2005; Delaloye et al., 2010; Buchli et al., 2013), suggesting that changes in the temperature of the rock glacier body through vertical heat conduction are an important influence on seasonal velocity variations (timing and amplitude; Kääb et al., 2005; Lambiel et al., 2005; Delaloye et al., 2010). Furthermore, the observed decrease in rock glacier velocities in winter was typically smooth and gradual and started a few weeks to months after the initiation of the seasonal cooling of GSTs (Delaloye et al., 2010; Wirz et al., 2015). The observed acceleration either occurred progressively and lagging behind the temperature increase (3-4 months after surface melt started; Kääb et al., 2005), or it occurred rapidly during the snowmelt period (Krummenacher et al., 2008; Perruchoud and Delaloye, 2007; Buchli et al., 2013; Wirz et al., 2015), indicating a potentially strong influence of meltwater infiltration.

Similarly, in addition to seasonal cycles, velocity observations with high temporal resolutions on the Furggwanghorn rock glacier (Buchli et al., 2013) and on the rock glaciers in the Mattertal discussed in this study (Wirz et al., 2015) detected strong peaks with very short durations of a few days during the snowmelt period. These observations suggest a very rapid and direct response of flow speeds to meteorological forcing, again likely involving infiltration of meltwa- ter. However, these studies have only made qualitative links between short-term variations in flow speed and external environmental forcing.

In this paper we therefore extend our previous work which focussed on extracting and describing the velocities of these three rock glaciers (see Wirz et al., 2015) by quantitatively exploring the link between surface velocity, and in particular short-term peaks, and meteorological and snowpack factors. We analyse a continuous time series of surface velocities from six GPS stations located on three rock glaciers in the Mattertal, Switzerland, with the factors analysed including GST, air temperature, precipitation, snow cover duration, and snowmelt period. Velocities are derived from GPS measurements over 3 years with a temporal resolution of 1 day and a spatial accuracy in the sub-centimetre range (Wirz et al., 2014).

Thus, we focus here on addressing the following research questions:

- Are continuous GPS measurements with high temporal resolutions consistent with previous observations of intra-annual variability in rock glacier movement?

- Can meteorological and snowpack factors influencing intra-annual variability in rock glacier velocity be quantitatively analysed, and how can these factors be related to a better process understanding? 

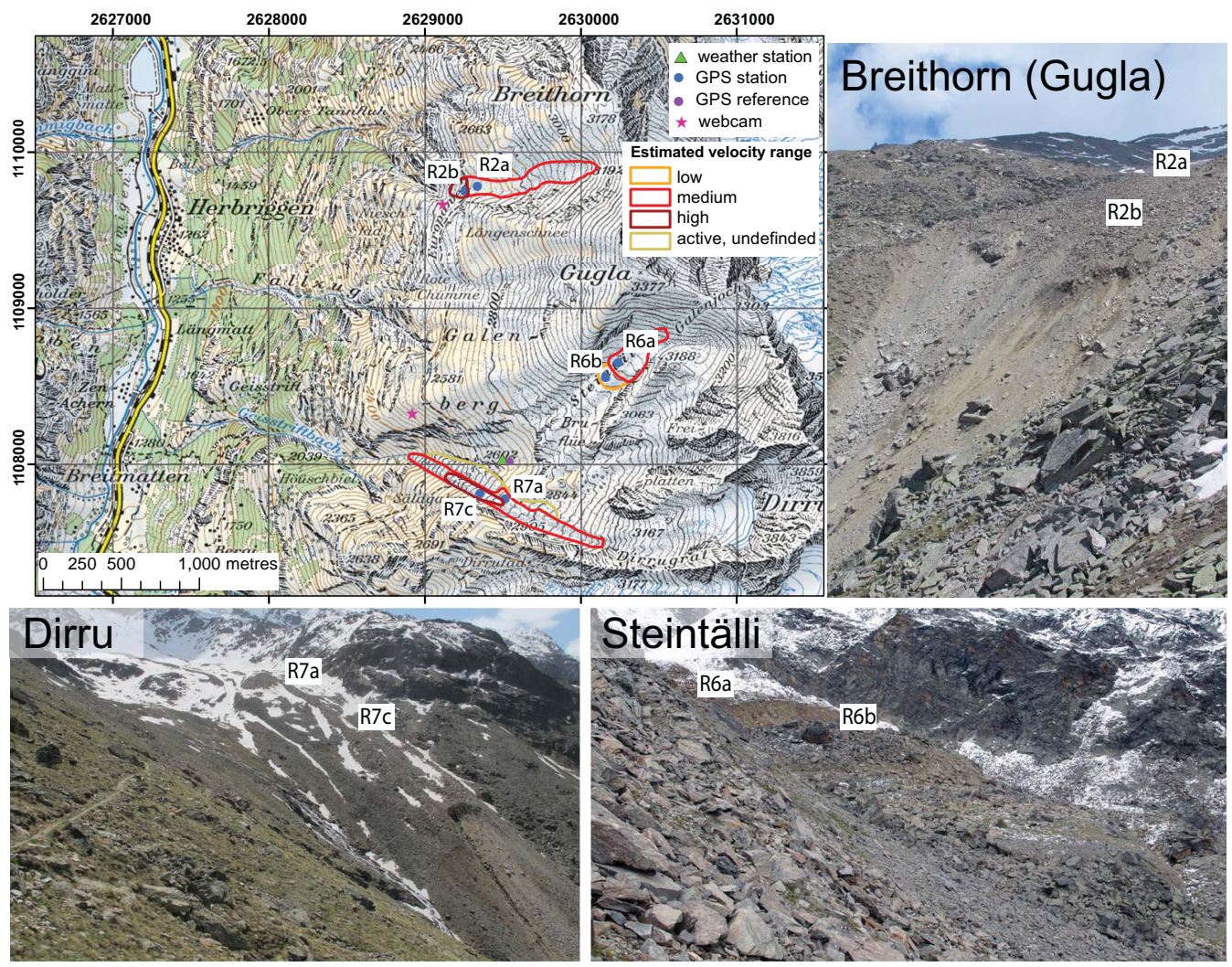

Figure 2. Overview of study site and main instrumentation. Estimated velocity range are a few decimetres per year for the category "low", several decimetres per year for the category "medium", and more than $1 \mathrm{~m}$ per year for the category "high". This was estimated based on field observations, expert knowledge (Hugo Raetzo, Federal Office for the Environment), and published observations (Delaloye et al., 2008b; Strozzi et al., 2009a, b; Delaloye et al., 2010, 2013; Wirz et al., 2015). Right and bottom: field impressions of rock glacier Breithorn (R2), Steintälli (R6), and Dirru (R7). Background: topographic map LK25 from the year 2013 reproduced by permission of Swisstopo BA15027.

\section{Study site}

The study site is located above the villages of Herbriggen and Randa on the orographic right side of the Mattertal in the Swiss Alps (see Fig. 2). Permafrost is likely to exist beneath much of the study area, especially above $2850 \mathrm{~m}$ a.s.l. (Boeckli et al., 2012). The main lithology is gneiss belonging to the crystalline Mischabel unit (Labhart, 1995).

Climate in the study area can be described as inner-alpine continental, with an average annual precipitation of $523 \mathrm{~mm}$ and mean annual air temperature of $5.2^{\circ} \mathrm{C}$ (long-term climatic mean (1961-1990) obtained from the closest MeteoSwiss station, located in Grächen, at $1550 \mathrm{~m}$ a.s.l., $9 \mathrm{~km}$ away from the study site). Over the experimental period of this study (20 August 2011-19 August 2014), the mean annual air temperature (MAAT) in Grächen was approximately $1{ }^{\circ} \mathrm{C}$ warmer and the mean annual precipitation was approximately $100 \mathrm{~mm}$ more than the long-term climatic mean. During this period a local weather station installed at the study site at $2697 \mathrm{~m}$ a.s.l. measured an MAAT of about $0.5^{\circ} \mathrm{C}$ and an average annual liquid precipitation of about $630 \mathrm{~mm}$. Due to a limitation of the instrument used (Vaisala WXT520), only liquid and not solid precipitation was measured.

Within the project PermaSense (http://www.permasense. ch), a total of 18 GPS stations were installed on various landforms within the study site (Wirz et al., 2015). Six of these GPS stations are located on three active rock glaciers within the boundaries of the study site. All three rock glaciers have a distinct morphology, and for two, exceptionally high movement rates at their tongues were detected by InSAR (Delaloye et al., 2008b; Strozzi et al., 2009a) and later confirmed by GPS measurements (Delaloye et al., 2013; Wirz et al., 2015). These active rock glaciers and their associated measurements constitute the core subjects studied within this paper. The GPS stations are installed on large well-grounded boulders in such a way that the displacement is as representative as possible for this rock glacier lobe (e.g. in the middle of the rock glacier lobe, not at its margins; further details on the strategy for the selection of GPS locations are given in Wirz et al., 2013). Table 2 gives an overview of the topographic, geomorphologic, and kinematic situation of each rock glacier. 
Table 2. Main characteristics regarding topography, morphology, and kinematics of the three investigated rock glaciers (Wirz et al., 2013; Delaloye et al., 2010, 2013; Wirz et al., 2015). Description of kinematics is based on expert knowledge (Dr. Hugo Raetzo, Federal Office for the Environment) and published observations (Delaloye et al., 2008b; Strozzi et al., 2009a, b; Delaloye et al., 2010, 2013; Wirz et al., 2015). In addition, for each GPS station the average velocities from summer 2011 to summer 2015 are given.

\begin{tabular}{|c|c|c|c|}
\hline $\begin{array}{l}\text { Rock glacier } \\
\text { unit }\end{array}$ & Topography & Morphology & Kinematics \\
\hline Breithorn R2 & $\begin{array}{l}\text { Situated in valley between the slopes } \\
\text { of Breithorn and Gugla; convex topog- } \\
\text { raphy, where } \sim 100 \mathrm{~m} \text { above the front, } \\
\text { the slope angle rapidly increases from } \\
\text { about } 20 \text { to } 35^{\circ} \text {. }\end{array}$ & $\begin{array}{l}\text { The unit consists of various lobes. The } \\
\text { main lobe can be divided into two } \\
\text { main zones: upper, flatter zone (R2a)- } \\
\text { transverse furrows and ridges indicating } \\
\text { compressive flow; lower zone (R2b) - } \\
\text { destabilized tongue with open cracks. }\end{array}$ & $\begin{array}{l}\text { Upper zone with average velocities } \\
\text { of several decimetres (R2a: } 1.7 \mathrm{ma}^{-1} \text { ); } \\
\text { lower steep zone (tongue) with veloc- } \\
\text { ities of several metres per year (R2b: } \\
6.8 \mathrm{ma}^{-1} \text { ). }\end{array}$ \\
\hline Steintälli R6 & $\begin{array}{l}\text { Situated in a small valley below the } \\
\text { peak Chli Dirruhorn; the upper lobe } \\
\text { (R6a) is slightly steeper }\left(20^{\circ}\right) \text { than the } \\
\text { lower lobe }\left(11^{\circ}, \text { R6b). }\right.\end{array}$ & $\begin{array}{l}\text { Two main lobes of different lithologies, } \\
\text { one above the other; steep fronts and } \\
\text { transversal furrow and ridges indicat- } \\
\text { ing compressive flow on both lobes. } \\
\text { Both lobes may originate from ice- } \\
\text { cored moraines. }\end{array}$ & $\begin{array}{l}\text { The upper lobe, moving at several } \\
\left.\text { decimetres per year (R6a: } 0.6 \mathrm{ma}^{-1}\right) \text {, } \\
\text { currently overrides the lower lobe, mov- } \\
\text { ing at a few decimetres per year (R6b: } \\
0.2 \mathrm{~m} \mathrm{a}^{-1} \text { ). }\end{array}$ \\
\hline Dirru R7 & $\begin{array}{l}\text { Below Dirru glacier, on the orographic } \\
\text { right side of Dirrugrat; convex topog- } \\
\text { raphy, where } \sim 400 \mathrm{~m} \text { above the front, } \\
\text { the slope angle rapidly increases from } \\
\text { about } 15 \text { to } 35^{\circ} \text {. }\end{array}$ & $\begin{array}{l}\text { The unit includes various tongues and } \\
\text { lobes from different generations with } \\
\text { different degrees of activity (inactive- } \\
\text { destabilized); the currently active lobe } \\
\text { can be divided into an upper, flatter } \\
\text { zone (R7a) with several ridges and fur- } \\
\text { rows, partly nested (both transversal } \\
\text { and longitudinal), and various depres- } \\
\text { sions; and a lower steep zone (R7c) } \\
\text { with a few longitudinal ridges but no } \\
\text { transversal ridge-furrow structure. }\end{array}$ & $\begin{array}{l}\text { Upper, flatter part moving at velocities } \\
\text { of several decimetres per year (R7a: } \\
1.2 \mathrm{ma}^{-1} \text { ); the steep fast-moving } \\
\text { tongue advancing with velocities } \\
\text { of several metres per year (R7c: } \\
\left.4.9 \mathrm{ma}^{-1}\right) \text {. }\end{array}$ \\
\hline
\end{tabular}

The rock glacier Breithorn (R2) is situated between the mountains Breithorn and Gugla and extends into the Bielzigji torrent (Fig. 2). It stretches from approximately 2550 to $2850 \mathrm{~m}$ a.s.1., is about $600 \mathrm{~m}$ long, 130 wide, and about $40 \mathrm{~m}$ thick (Delaloye et al., 2013). It has a convex profile curvature: approximately $100 \mathrm{~m}$ above the front the slope angle rapidly increases from about 20 to $35^{\circ} .{ }^{1}$ GPS station $\mathrm{R} 2 \mathrm{a}^{2}$ is located on the flatter part of the rock glacier at 2704 ma.s.l. that also moves more slowly than the steeper frontal part (tongue) where GPS R2b is located at $2650 \mathrm{ma}$.s.l. (Delaloye et al., 2013; Wirz et al., 2015). Since about 1995 this tongue has accelerated to about $2-3 \mathrm{ma}^{-1}$. The cause of this acceleration is not well known but has been attributed to a combination of the effects of topography, geometry of the landform, and increased permafrost temperatures over the last 2 decades (Delaloye et al., 2013).

The rock glacier Steintälli (R6) consists of two superimposed lobes of different sediment lithologies and moving at different velocities (Fig. 2). The rock glacier is approximately $550 \mathrm{~m}$ long and $160 \mathrm{~m}$ wide, and each lobe is about $25 \mathrm{~m}$ thick (derived from analysis of a digital elevation model with a resolution of $2 \mathrm{~m}$ ). The upper lobe currently over-

\footnotetext{
${ }^{1}$ Slope angles were derived from a digital elevation model with a resolution of $25 \mathrm{~m}$ (DEM25).

${ }^{2}$ The names for the different rock glaciers and GPS stations have been adopted from Wirz et al. (2015).
}

rides the lower lobe. The GPS station at position R6a is located at 3020 ma.s.1., with a slope angle of $20^{\circ}$ on the upper lobe, while position R6b is located on the lower lobe at 2991 ma.s.1. and has a slope angle of $15^{\circ}$.

The rock glacier Dirru (R7) is composed of various lobes and fronts (Fig. 2), originating from different rock glacier generations (Delaloye et al., 2013). The currently active lobe, which is located on the orographic right side of Dirrugrat, has a total length of more than $1 \mathrm{~km}$, is about 60 to $120 \mathrm{~m}$ wide, and is approximately $20 \mathrm{~m}$ thick (Delaloye et al., 2013). It has a convex profile and slope angles increase from about $15^{\circ}$ in the upper part to more than $30^{\circ}$ in the lower part towards its front. Since the 1970/80s this frontal steep part (tongue) has progressively accelerated and reached surface velocities above $5 \mathrm{ma}^{-1}$, potentially indicating a phase of destabilization (Delaloye et al., 2013). From 2008 to 2010 velocities measured at the front of R7 using manually executed annual GPS surveys have decreased slightly (Delaloye et al., 2013) with recent increases observed since 2011 (Wirz et al., 2015). The GPS station at position R7a is located on the upper flatter part at $2772 \mathrm{~m}$ a.s.1. The GPS at position R7c was installed on a small longitudinal ridge at $2673 \mathrm{~m}$ a.s.1. more or less in the middle of the steep fast-moving tongue.

Further details on the description of the individual rock glaciers as well as a detailed description of the field instrumentation can be found in Wirz et al. (2015). 


\section{Data and methods}

\subsection{GPS and inclinometer data}

Each GPS station consists of a low-cost single-frequency GPS receiver (u-blox LEA-6T) with an active antenna (Trimble Bullet III) and a two-axis inclinometer (VTI SCA830D07) mounted on a mast $1-1.5 \mathrm{~m}$ above ground (Beutel et al., 2011; Buchli et al., 2012; Wirz et al., 2015). GPS sensors as well as inclinometers are sampled continuously at $30 \mathrm{~s}$ and 2 min intervals respectively. From this primary raw data, daily position solutions and inclinometer values are computed. A static approach based on a single-frequency differential carrier-phase technique with short baselines $(0.2$ to $1.5 \mathrm{~km}$, using the Bernese software) was used for the postprocessing of the raw GPS to positioning data (Limpach and Grimm, 2009; Dach et al., 2007). The standard deviation (SD) of the GPS position solutions derived is typically about $1.5 \mathrm{~mm}$ in the horizontal and about $3.5 \mathrm{~mm}$ in the vertical direction, and related covariances are small $(<0.01 \mathrm{~mm}$, Wirz et al., 2014). The inclinometer measurements mounted directly on the GPS mast allow correction of GPS positions for mast tilt (Wirz et al., 2014). SDs in inclination $(\theta)$ are typically around $0.4^{\circ}$, and they are around $2.5^{\circ}$ for the orientation (az) of the mast tilt. It has been found that the correction for mast tilt is only appropriate where tilting is greater than the accuracy of the inclinometer measurements (see Supplement and Wirz et al., 2014).

GPS position data were collected continuously between summer 2011 and summer 2014. However, all stations have some data gaps complicating the data analysis and interpretation. During the first winter (2011/12) a 30-day gap occurred for all positions, due to a power outage at the GPS reference location, which did not allow a differential processing of the GPS positions. Position R7a has a large data gap from 17 July 2012 to 23 April 2013 caused by a missing instrument. For this study we structure the total study period from 20 August 2011 to 19 August 2014 into three periods of 1 year each: the study years 2011/12, 2012/13 and 2013/14 lasting from 20 August of the first year to 19 August of the following year; for example, the study year 2011/12 lasts from $20 \mathrm{Au}-$ gust 2011 to 19 August 2012.

\subsection{Meteorological and auxiliary data}

GST is measured next to each GPS station within a radius of about $7 \mathrm{~m}$ using five miniature temperature loggers (Maxim iButton DS1922L; see Gubler et al., 2011). These temperature loggers were distributed in small spaces between the surrounding boulders at depths of approximately 5 to $30 \mathrm{~cm}$ to prevent direct solar exposure. Those GST measurements have an accuracy of $\pm 0.5^{\circ} \mathrm{C}$ (near $0^{\circ} \mathrm{C}$; Gubler et al., 2011) and a temporal resolution of $3 \mathrm{~h}$. For each GPS station, a daily mean GST was calculated by averaging across all measurements of the respective temperature data loggers deployed at the site in question. Applying the approach of Schmid et al.
(2012), the duration of the winter snow cover and zero curtain period were derived from GST. The zero curtain period is defined as the duration of the zero curtain, the effect of latent heat in maintaining temperatures near $0^{\circ} \mathrm{C}$ over extended periods in freezing or thawing soils (see, e.g., Outcalt et al., 1990). The zero curtain period is defined as period during which at least for one iButton a zero curtain was detected. Winter snow cover and the zero curtain period were calculated for each individual station as well as jointly across all GST data points at the study site (Wirz et al., 2015).

Air temperature and liquid precipitation, measured at the local weather station (Vaisala WXT520, Fig. 2), are available with a temporal resolution of $2 \mathrm{~min}$ and an accuracy of $\pm 0.3^{\circ} \mathrm{C}$ for air temperature and $\pm 5 \%$ for liquid precipitation measurements. Air temperature was aggregated to a daily mean value. The measured amount of liquid precipitation was aggregated for daily mean and daily maximum.

Three webcams distributed within the study site provide additional information about (actual) surface characteristics (Fig. 10). Based on these daily webcam images taken at noon, for each day it was subjectively classified whether new snow (true/false), strong melt (true/false), a wet front (values: 1 - clearly absent; 2 - possibly absent; 0 - no statement possible; 3 - visible to some extent; 4 - clearly visible), or water outflow were visible at the active front of each rock glacier (see Fig. 10).

\subsection{Velocity estimations using SNRT}

For the calculation of the magnitude of the horizontal velocity ( $v$; in this paper, referred to as velocity) and the direction of movement (azi $\mathrm{i}_{v}$ ), the SNRT (signal-to-noise thresholding) method was applied. Detailed information and a discussion of limitations and advantages of this method are given in Wirz et al. (2014). When using SNRT, temporal resolution (duration of applied smoothing window, here called velocity period) directly depends on the signal-to-noise ratio (SNR) of the position data and therefore varies with time.

For each velocity period the SNR must be higher than a predefined threshold (SNR-t). A suitable SNR-t is found empirically (Wirz et al., 2015), using a similar approach as Laube and Purves (2011). In this study, a threshold of 40 seems optimal because (a) the influence of noise on estimated velocities is strongly reduced and (b) the same SNR-t can be applied for comparatively slow $\left(\leq 0.5 \mathrm{~m} \mathrm{a}^{-1}\right)$ and fast $\left(\geq 4 \mathrm{ma}^{-1}\right)$ stations, facilitating the comparison of individual stations (Wirz et al., 2015). The sensitivity of the timing of velocity changes to SNR-t is reported in Sect. 4.1.

Mean annual horizontal velocities of each study year $\left(\mathrm{MAV}_{12}, \mathrm{MAV}_{13}, \mathrm{MAV}_{14}\right)$ are given as total horizontal displacements divided by time and were only calculated if at least one data point existed within the first and last 10 days of the period. $\mathrm{MAV}_{12-14}$ refers to the mean velocity over the entire measurement period. Interannual variability between the study years $(2011 / 12,2012 / 13$, and 2013/14) was calcu- 
Table 3. Overview of potential explanatory variables used. As potentially important time periods, we used days during the peak, also including the total of days during the peak and 7 days before the peak. For precipitation for the logistic regression models, a log transformation was applied $(\log )$.

\begin{tabular}{|c|c|c|c|}
\hline Name & Description & Data used & $\log$ \\
\hline Prec & mean daily rainfall & weather station at the study site & yes \\
\hline mPrec & maximum daily rainfall & weather station at the study site & yes \\
\hline PDD $_{\text {air }}$ & $\begin{array}{l}\text { mean number of positive degree days derived from daily } \\
\text { mean air temperature }\end{array}$ & weather station at the study site & no \\
\hline PDD $_{\text {gst }}$ & mean number of positive degree days derived from GST & GST of iButtons next to the GPS & no \\
\hline n.snow & mean number of days with fresh snow & Webcam images & no \\
\hline zc.ind & index for zero curtain derived from GST (yes/no) & GST of iButtons next to the GPS & no \\
\hline snow.ind & $\begin{array}{l}\text { index for insulating snow cover derived from GST } \\
\text { (yes/no) }\end{array}$ & GST of iButtons next to the GPS & no \\
\hline $\begin{array}{l}\text { With } \\
\text { adjunct }\end{array}$ & Time period & Example & \\
\hline 0 & Days during velocity period & Prec.0 & \\
\hline 7 & Days during velocity period as well as 7 days before & Prec.7 & \\
\hline
\end{tabular}

lated with respect to the MAV of the previous year. The intraannual variability in velocity of each GPS station is given as relative deviation to the $\mathrm{MAV}_{12-14}$. The SNR of velocities in the vertical direction is much lower and therefore does not allow the investigation of the intra-annual variability.

\subsection{Detection of peaks in velocity data}

Especially at two GPS stations (R2b, R7c) sudden strong peaks in velocities were observed (Wirz et al., 2015). We here define a peak as a velocity period where (a) the velocity is distinctly higher, both compared to the velocity before and after the peak, and (b) the strength of the peak ( $\operatorname{diff}_{\mathrm{p}}$ ) must be greater than a threshold $t_{\mathrm{p}}$. Diff $\mathrm{p}$ is the percentage velocity ratio between the peak velocity and the mean $(\mu)$ of the previous $\left(v_{i-1}\right)$ and following $\left(v_{i+1}\right)$ velocity periods $\left(\right.$ diff $\left._{\mathrm{p}}=\frac{v_{i}}{\mu_{\left(v_{i-1}, v_{i+1}\right)}}\right)$. The detection of peaks depends on (a) the SNR-t used to calculate velocities (here SNR-t $=40$ ) and (b) the threshold $t_{\mathrm{p}}$ (here $t_{\mathrm{p}}=6$ ) used for the peak detection (Fig. 9, Sect. 4.1)

\subsection{Analysis of velocity peaks}

To investigate the relationship between individual meteorological factors (see Sect. 3.2) and the occurrence of a peak in velocity, we applied both qualitative and quantitative analyses. All analyses are performed with the software R using the packages MASS (Venables and Ripley, 2002) and pROC (Robin et al., 2011). As potential explanatory variables we used the following: cumulative amount and maximum of daily amount of liquid precipitation (Prec. and mPrec.), cumulative amount of positive degree days of air temperature $\left(\mathrm{PDD}_{\mathrm{air}}\right)$ and GST $\left(\mathrm{PDD}_{\mathrm{gst}}\right)$, the number of days with visible fresh snow (n.snow), and the number of days during the zero curtain period (zc; Table 3). All variables were calculated once for the duration of the peak only and once for the days during and 7 days before peak. Because the duration of the peaks varies, the cumulative amount is normalized by the duration of the peak (number of days).

To visualize potential relationships between individual explanatory variables and the occurrence of peaks, we used spineplots (Friendly, 1994), showing the frequencies of the occurrence of velocity peaks as opposed to the absence of velocity peaks (later called no-peak periods) in relation to potential meteorological variables. The width of the individual bars relate to the $25 \%$ quantiles of the explanatory variable. Since a range of processes and meteorological variables may have been relevant for the occurrence of peaks during snow cover and snow-free conditions, we distinguished between periods with an insulating snow cover (snow cover period) and without (snow-free period). The snow cover period includes the days where an insulating snow cover can be derived from GST data (Sect. 3.2). In addition, binary values $(0 / 1)$ are applied to distinguish between periods during and outside the zero curtain period, which was also derived from GST measurements.

In order to quantify the importance of the individual variables, we applied the Wilcoxon rank-sum test (Baur, 1972), with the alternative hypothesis that the distribution of explanatory variables differs for peak periods and no-peak periods. Based on this preliminary analysis, relevant explanatory variables could be preselected.

Logistic regressions were used to study the relationship between a set of explanatory variables and a binary response variable, such as avalanche release (Jomelli et al., 2007) or the occurrence of debris flows (Xu et al., 2012), landslides (Bernknopf et al., 1988; Ohlmacher and Davis, 2003; Can et al., 2005), or rock glaciers (Brenning and Trombotto, 
Table 4. Characteristics of individual GPS stations. $N$ : number of daily GPS solutions obtained; from and to: measurement period; disp tot $_{\text {: }}$ total displacement; $\sigma_{\text {disp: }}$ standard deviation of total displacement (estimated based on 2000 Monte Carlo simulations); disp-ele tot: total vertical displacement; disp-ele $\alpha$ : vertical displacement related to surface slope angle with related uncertainties from $5^{\circ}$ variations in surface slope ; $\mathrm{MAV}_{12-14}$ : mean velocity for the entire measurement period; $\mathrm{MAV}_{12}, \mathrm{MAV}_{13}$, and $\mathrm{MAV}_{14}$ : mean annual velocities. Note that for R2a only GPS measurements since 23 February 2012 exist and, thus, results for MAV $12-14$ and especially R2a results for MAV 12 may not be fully representative of the "true" displacement for the period 2011/12. For R7a, there is a data gap from summer 2012 to spring 2013.

\begin{tabular}{|c|c|c|c|c|c|c|c|c|c|c|c|c|c|c|}
\hline Pos. & $N$ & From & To & $\begin{array}{r}\text { disp tot }_{\text {tot }} \\
(\mathrm{m})\end{array}$ & $\begin{array}{c}\sigma_{\text {disp }} \\
(\mathrm{mm})\end{array}$ & $\begin{array}{r}\text { disp-ele }_{\text {tot }} \\
(\mathrm{m})\end{array}$ & $\begin{array}{r}\text { disp-ele }{ }_{\alpha} \\
(\mathrm{m})\end{array}$ & $\begin{array}{r}\mathrm{MAV}_{12-14} \\
\left(\mathrm{ma}^{-1}\right)\end{array}$ & $\begin{array}{l}\mathrm{MAV}_{12} \\
\left(\mathrm{ma}^{-1}\right)\end{array}$ & $\begin{array}{l}\mathrm{MAV}_{13} \\
\left(\mathrm{ma}^{-1}\right)\end{array}$ & $\begin{array}{l}\mathrm{MAV}_{14} \\
\left(\mathrm{ma}^{-1}\right)\end{array}$ & $\begin{array}{r}\text { MAGST }_{12} \\
\left({ }^{\circ} \mathrm{C}\right)\end{array}$ & $\begin{array}{r}\text { MAGST }_{13} \\
\left({ }^{\circ} \mathrm{C}\right)\end{array}$ & $\begin{array}{r}\text { MAGST }_{14} \\
\left({ }^{\circ} \mathrm{C}\right)\end{array}$ \\
\hline R2a & 846 & 25 February 2012 & 19 August 2014 & $4.29^{1}$ & 0.006 & $1.59^{1}$ & $2.0^{1}(0.5)$ & $1.7^{1}$ & $1.4^{2}$ & 1.6 & 2.0 & NA & 0.93 & 0.59 \\
\hline$R 2 b-f$ & 981 & 20 August 2011 & 19 August 2014 & 20.32 & 0.01 & 14.97 & 13.7 (2.7) & 6.8 & 5.9 & 7.1 & 7.3 & 1.38 & 1.09 & 1.67 \\
\hline R6a & 958 & 20 August 2011 & 19 August 2014 & 1.70 & 0.006 & 0.25 & $0.62(0.2)$ & 0.6 & 0.4 & 0.6 & 0.7 & 0.26 & 0.31 & 0.02 \\
\hline R6b & 1003 & 20 August 2011 & 19 August 2014 & 0.65 & 0.005 & 0.15 & $0.17(0.1)$ & 0.2 & 0.2 & 0.2 & 0.2 & 0.53 & 0.37 & -0.11 \\
\hline R7a & 700 & 20 August 2011 & 19 August 2014 & $5.00^{3}$ & 0.005 & $1.60^{3}$ & $1.1(0.3)$ & $1.6^{3}$ & $1.4^{4}$ & NA & 1.7 & 0.31 & -0.45 & 0.03 \\
\hline $\mathrm{R} 7 \mathrm{c}$ & 784 & 20 August 2011 & 19 August 2014 & 14.59 & 0.006 & 9.62 & $9.5(1.9)$ & 4.9 & 4.2 & 4.3 & 6.1 & 0.38 & 0.15 & 0.38 \\
\hline
\end{tabular}

2006). In this study, the occurrence of a peak is the binary variable, and the logistic model has the form of

$\operatorname{logit}(x)=\ln \frac{\Pi(x)}{1-\Pi(x)}=\beta^{\mathrm{T}} x$

where $\Pi(x)$ is the conditional probability of the occurrence of a peak given a set of explanatory variables $x$, and $\beta$ is a coefficient vector determining the contribution of each explanatory variable to a prediction (Hosmer et al., 2013). The odds of $\Pi(x)$ are given by the ratio of $\Pi(x) /(1-\Pi(x))$. If the variable $x_{i}$ with coefficient $\beta_{i}$ is increased by one unit, the odds of $\Pi(x)$ change by a factor of $e^{\beta_{i}}$.

All periods of both stations (R2b and R7c) were included in the logistic regression models (number of periods used for logistic regression models: $N=276$; with $N$ peaks $=37$ and a median duration of the velocity periods of 6 days). As potential variables for the logistic regression, all variables with a significant $P$ value from the Wilcoxon rank-sum test $\left(p_{\mathrm{w}} \leq 0.05\right)$ were selected. In addition, interaction terms with the indices for snow cover (snow.ind), for zero curtain (zc.ind), and for position (R2b and R7c) were included in the models to account for seasonal effects and differences between the individual rock glaciers. As precipitation is not normally distributed, we applied a log transformation for Prec. and mPrec. To obtain the most appropriate models (later called final models), an iterative stepwise model selection by the Akaike information criterion was applied (AIC; Venables and Ripley, 2002). Final model performance was evaluated using the area under the receiver-operating characteristics curve (AUROC; Hosmer et al., 2013).

\section{Results and interpretation}

\subsection{Sensitivity tests for peak detection}

Applying different SNR-t values has a negligible influence on the observed seasonal variability for all stations (e.g., Fig. 9b). The detection of peaks, however, is sensitive to the applied thresholds. The higher the SNR-t, the fewer peaks are detected and the start of a peak is often delayed (Fig. 9a and $b$ ). Hence, for SNR-t a balance between the reliability of a peak and the detection of all peaks needs to be considered.

For small SNR-t $(<20)$, velocities are influenced by noise and, hence, velocity peaks are potentially caused by noise in the GPS positions (Wirz et al., 2014). For higher SNR$\mathrm{t}(\geq 30)$, variability is strongly reduced, velocities become more stable, and differences between the variability in estimated velocities (and detected peaks) for different SNR-t become smaller. In addition, the number of peaks during winter (December-March) is strongly reduced. However, with an SNR-t of 40, peaks were almost solely detected for stations with high velocities (R2b and R7c). Furthermore, the number of detected peaks also depends slightly on the applied threshold $t_{\mathrm{p}}$ (Fig. 9c). The influence of $t_{\mathrm{p}}$ is larger for $\mathrm{R} 2 \mathrm{~b}$ than for R7c. For R7c, for $t_{\mathrm{p}} \geq 3 \%$ the number of peaks is almost stable. For $\mathrm{R} 2 \mathrm{~b}$, with $t_{\mathrm{p}} \geq 6 \%$ the number of peaks becomes quite stable and detected peaks correspond well with manually identified peaks.

We studied the sensitivity of our statistical analysis of peaks to a change in SNR-t $(20,40)$ and $t_{\mathrm{p}}(6,10)$ and found that a change in the SNR-t and $t_{\mathrm{p}}$ has little influence (Tables S3, S4, and S6 in the Supplement): for example, independent of the applied thresholds, the estimates for precipitation, temperature, and zero curtain are similar in all final models and the highest AUROC ("best" model) was always obtained if precipitation and $\mathrm{PDD}_{\mathrm{gst}}$ during the peak were included.

\subsection{Mean velocities and their interannual variability}

The average mean annual horizontal velocities $\left(\mathrm{MAV}_{12-14}\right)$ in the study site over the 3 study years ranged from 0.2 to $6.5 \mathrm{~m} \mathrm{a}^{-1}$ (Table 4) and confirmed earlier observations based on 2 years of data (Wirz et al., 2015). Highest velocities were measured at the steep fronts of the rock glaciers Breithorn (R2b: $6.5 \mathrm{ma}^{-1}$ ) and Dirru (R7c: $4.9 \mathrm{ma}^{-1}$ ). The average 


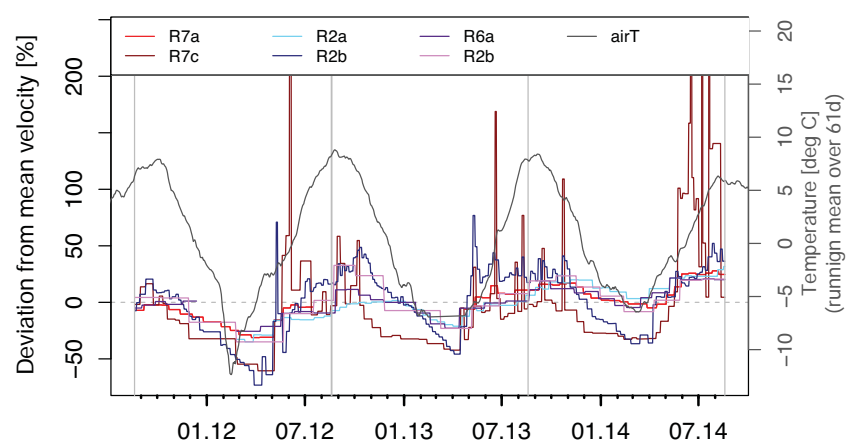

Figure 3. Intra-annual variability in horizontal velocities. Left $y$ axis: intra-annual variability, expressed as deviation from $\mathrm{MAV}_{12-14}$. Right $y$ axis: filtered air temperature (running mean over 61 days). Vertical grey lines separate the 3 different years of observation (2011/12, 2012/13, 2013/14).

vertical displacement ranges from $5 \mathrm{~cm}$ to more than $5 \mathrm{~m}$ per year. A comparison with expected vertical movement from horizontal displacement and slope angle indicates a slight thinning for stations R2b and R7a and a slight thickening for the stations R2a and R6a, but uncertainties are high and are not conclusive regarding mass change in these rock glaciers. On both the Dirru and Breithorn rock glacier, the 3-4 times faster flow of the lower compared to the upper stations indicated extensional flow. By contrast, the much slower Steintälli rock glacier instead shows compressional flow.

At all stations, mean annual velocities (MAV) increased over the entire observation period ( $2-42 \%$, Table 4$)$, and this is most pronounced for R2a (Fig. 4). However, the percentage increase from year to year is not simultaneous between stations. The winter minima in velocity increased for all stations from the study year 2011/12 to 2013/14.

At the study site and at the MeteoSwiss weather station in Grächen (1550 ma.s.1.), both MAAT and average mean annual ground temperatures (MAGST) over all iButtons were highest in the study year 2011/12 and lowest in 2012/13 Table 4). In contrast, in winter (mean of January and February), both air temperature and GST were lowest in 2011/12 and highest in 2013/14 (Fig. 3), both at the study site and in Grächen.

The annual amount of precipitation at the study site and at the MeteoSwiss station in Zermatt (1638 ma.s.1.) was highest in the period 2013/14 and lowest in 2012/13, whereas in Grächen the annual amount of precipitation was about $+10 \%$ higher in 2012/13 than in 2011/12 and 2012/13. The snow cover duration at the study site derived from GST was longest during the period 2012/13 (226 days, median of GST measurements) and shortest in 2013/14 (195 days; 2011/12: 218 days).
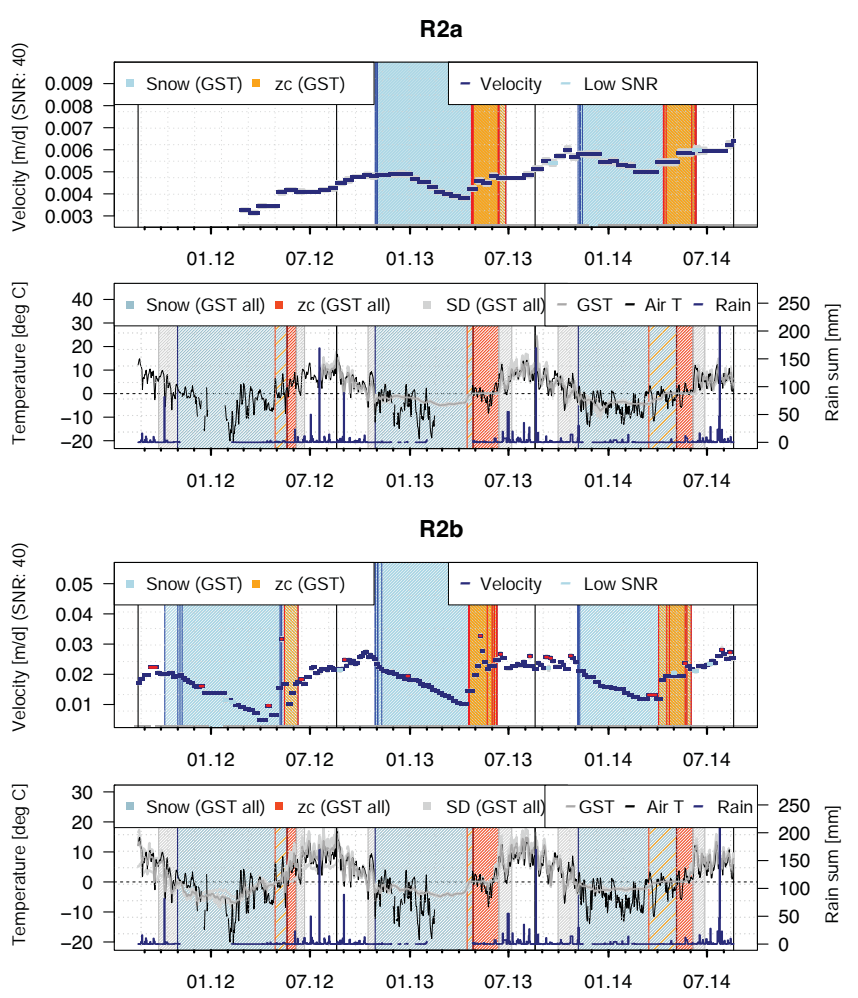

Figure 4. Comparison of the horizontal velocities to meteorological factors for Breithorn rock glacier (R2a and b). Vertical black lines separate the 3 different years of observation (2011/12, 2012/13, 2013/14). Top: horizontal velocity (dark blue), its standard deviation (grey), and velocity periods detected as peaks (red dots), periods with an SNR below SNR-t are indicated in light blue. Grey dots at the bottom indicate days with available GPS positions. Zero curtain period (orange) and insulating snow cover (light blue) are both estimated from individual iButtons next to the GPS station (the vertical blue lines indicate the start of insulating snow cover at the individual iButtons and the vertical orange line represents the end of the zero curtain period). Bottom: daily amount of liquid precipitation (dark blue bars), air temperature (black line), and GST (grey line, iButtons next to GPS station; bold line refers to the median over all iButtons). Insulating snow cover (blue, earliest in grey) and zero curtain periods (dark orange, earliest shaded in orange, latest in grey) as derived from all iButtons in the study area.

\subsection{Intra-annual variability: seasonal}

At all stations, horizontal velocities have a quasi-sinusoidal form over each year, with a maximum in autumn (often around October, if neglecting the short velocity peaks at $\mathrm{R} 2 \mathrm{~b}$ and $\mathrm{R} 7 \mathrm{c}$ ) and a minimum in late winter or early spring (often around March, Figs. 3, 4, 5, and 6). Briefly, the minimum in velocity occurred the latest in the study year 2012/13 and earliest in 2013/14. The amplitudes of the intra-annual variability range from less than 30 to more than $2000 \%$, with greatest amplitudes at R7c ( $\geq 240 \%$ ), especially in the period 2013/14 $(2800 \%)$. Also at R2b, the intra-annual variability was large and above $80 \%$. For the other stations (R2a, 

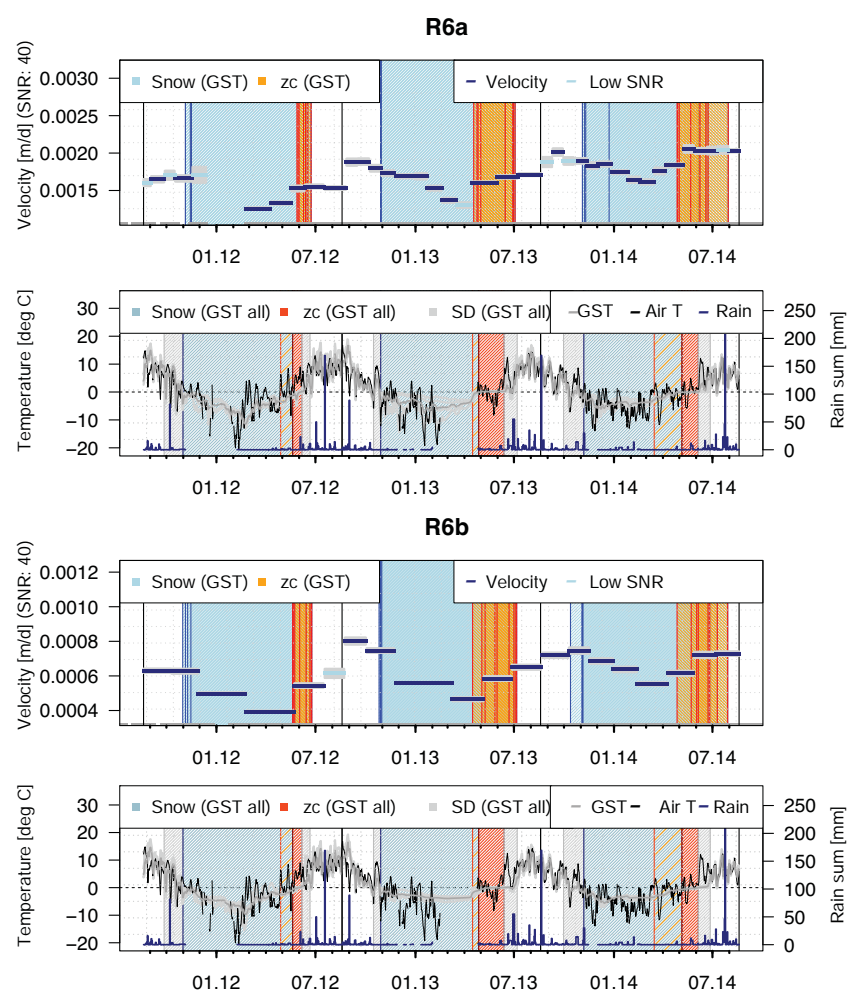

Figure 5. As Fig. 4 but for rock glacier Steintälli (R6a and b).
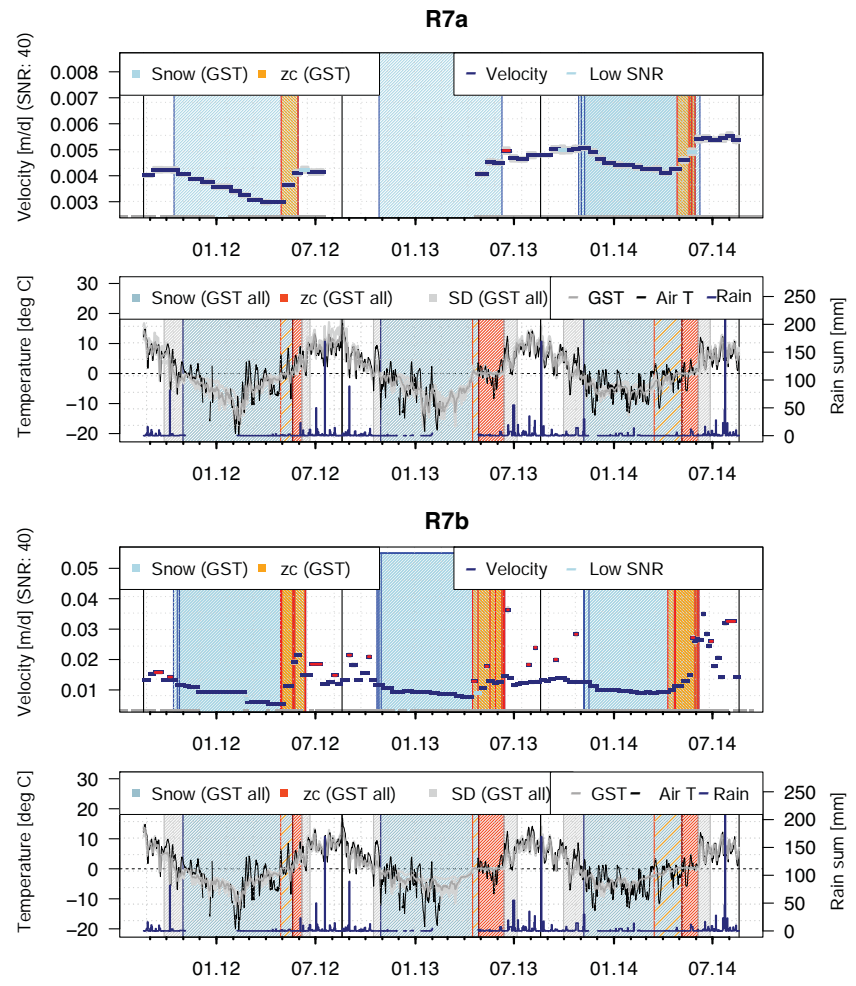

Figure 6. As Fig. 4 but for rock glacier Dirru (R7a and b).
R6a, R6b, R7a) the yearly amplitude in velocity was around $30 \%$ (from -15 to $+15 \%$ ). At individual stations the amplitudes were similar in the different years (Fig. 3).

The exact timing of acceleration and deceleration is often difficult to clearly determine because either additional short peaks in velocity occurred (R2b and R7c; see next section) or the temporal resolution differs between individual stations or is too coarse (e.g. $>1$ months for R6b). Nevertheless, some observations can be made: spring acceleration of different stations and for different years started between March and May, frequently in April. The winter deceleration started between September and December, mostly in October. Differences in the start of winter deceleration between individual stations were larger ( $\sim 3$ months) compared to the differences in the start of spring acceleration $(\sim 3$ weeks). For all rock glaciers, the deceleration started earlier at lower (R2b, R6b, R7c) than at upper stations (R2a, R6a, R7a). Where data are available, the deceleration started latest at R2a (December). Importantly, the acceleration in spring always started during the zero curtain period (Figs. 4, 5, and 6). Furthermore, the timing of acceleration frequently occurred nearly simultaneously for the individual stations located upon the same rock glacier (e.g. R7a and R7c in 2011/12 and 2013/14 (R7a has no data in 2012/13); Figs. 3 and 6).

For the stations on R2 and R7, spring acceleration occurred more abruptly than the continuous and smooth deceleration in winter (Fig. 3). For R6a, and especially R6b, this is less clear because of lower flow speeds and the resulting coarser resolution in velocity periods (R6b: $27 \mathrm{~d}$; R6b: $69 \mathrm{~d}$ ). Nevertheless, also for R6a, a strong increase in velocity is visible during zero curtain in all study years with available data. Furthermore, at four stations (R2b, R6a, R6b, R7a), the movement direction during the period of acceleration differs slightly from that during the period of deceleration. At all these stations, the movement direction pointed slightly more $\left(12-15^{\circ}\right)$ towards the north during the period of acceleration and towards the south during the phase of deceleration.

Over the entire observation period, the yearly maxima in air temperature and GST (running mean over 60 days) were in all 3 study years rather similar and typically occurred in late August or September (Fig. 3). By contrast, minimum values for GST and air temperature in winter increased over the 3 study years. Lowest air temperatures and GST were observed in February and March. The phase lag between temperature (air and GST) and velocity differs among the individual stations and years and is often difficult to determine (Fig. 3). It ranges from less than 1 month (R6a; minimum in 2011/12) to more than 3 months (R2a; maximum in 2012/13). As both the depth where the main movement occurs and the thermal conditions of the rock glacier body are unknown, we did not perform any statistical analyses on the observed seasonal variability in the rock glacier velocities. 
Table 5. Peaks observed at R2b and R7a during the 3 different study years. For each year and for both stations, the duration (days) of the snow-free, the snow cover, and the zero curtain period, the number of peaks per period (snow-free, snow cover, zero curtain; the number

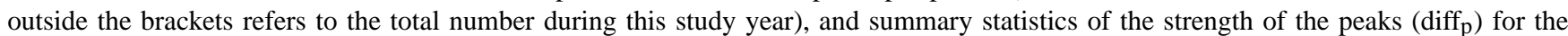
different periods are given. The first number in brackets refers to the snow-free, the second to the snow cover (excluding days with zero curtain), and the third to the zero curtain period. Both winter snow cover and the zero curtain period are derived from GST measurements next to the GPS station (Sect. 3.2).

\begin{tabular}{|c|c|c|c|c|c|c|c|c|c|c|c|c|}
\hline \multirow[t]{2}{*}{ Study year } & \multicolumn{2}{|c|}{ Duration: } & \multicolumn{2}{|c|}{ N Peaks: } & \multicolumn{2}{|c|}{$\operatorname{Min}\left(\operatorname{diff}_{p}\right)$ : } & \multicolumn{2}{|c|}{$\operatorname{Max}\left(\operatorname{diff}_{p}\right):$} & \multicolumn{2}{|c|}{ Mean $\left(\right.$ diff $\left._{p}\right)$ : } & \multicolumn{2}{|c|}{ Median $\left(\operatorname{diff}_{p}\right)$ : } \\
\hline & $\mathrm{R} 7 \mathrm{c}$ & $\mathrm{R} 2 \mathrm{~b}$ & $\mathrm{R} 7 \mathrm{c}$ & $\mathrm{R} 2 \mathrm{~b}$ & $\mathrm{R} 7 \mathrm{c}$ & $\mathrm{R} 2 \mathrm{~b}$ & $\mathrm{R} 7 \mathrm{c}$ & $\mathrm{R} 2 \mathrm{~b}$ & $\mathrm{R} 7 \mathrm{c}$ & $\mathrm{R} 2 \mathrm{~b}$ & $\mathrm{R} 7 \mathrm{c}$ & $\mathrm{R} 2 \mathrm{~b}$ \\
\hline $2011 / 12$ & $(143,197,26)$ & $(126,220$, & $5(4,0,1)$ & $5(2,3$, & NA, 314) & $(7,9, N$ & $(37, \mathrm{NA}, 3$ & $(11,98)$, & $(19, \mathrm{NA}, 314)$ & $(9,57, \mathrm{NA})$ & $(15, \mathrm{NA}, 314)$ & $(9,56, \mathrm{NA})$ \\
\hline $2012 / 13$ & $(130,176,59)$ & $(142,172,51)$ & $7(5,0,2)$ & $5(3,1,1)$ & $(37, \mathrm{NA}, 50)$ & $(6,7,30)$ & $(155, \mathrm{NA}, 52)$ & $(14,7,30)$ & $(75, \mathrm{NA}, 51)$ & $(10,7,29)$ & $(49, \mathrm{NA}, 51)$ & $(11,7,30)$ \\
\hline $2013 / 14$ & $(154,154,57)$ & $(157,148,60)$ & $8(7,0,1)$ & $7(5,1,1)$ & $(22, \mathrm{NA}, 33)$ & $(7,12,11)$ & $(2424, \mathrm{NA}, 34)$ & $(16,12,12)$ & $(548, \mathrm{NA}, 33)$ & $(10,12,12)$ & $(102, \mathrm{NA}, 33)$ & $(10,12,12)$ \\
\hline Total & & & $20(16 / 0 / 4)$ & $17(10 / 5 / 2)$ & $(7, \mathrm{NA}, 33)$ & $(6,7,12)$ & $(2424$, NA, 314$)$ & $(17,98,30)$ & $(268, \mathrm{NA}, 213)$ & $(10,38,21)$ & $(46, \mathrm{NA}, 51)$ & $(10,12,21)$ \\
\hline
\end{tabular}

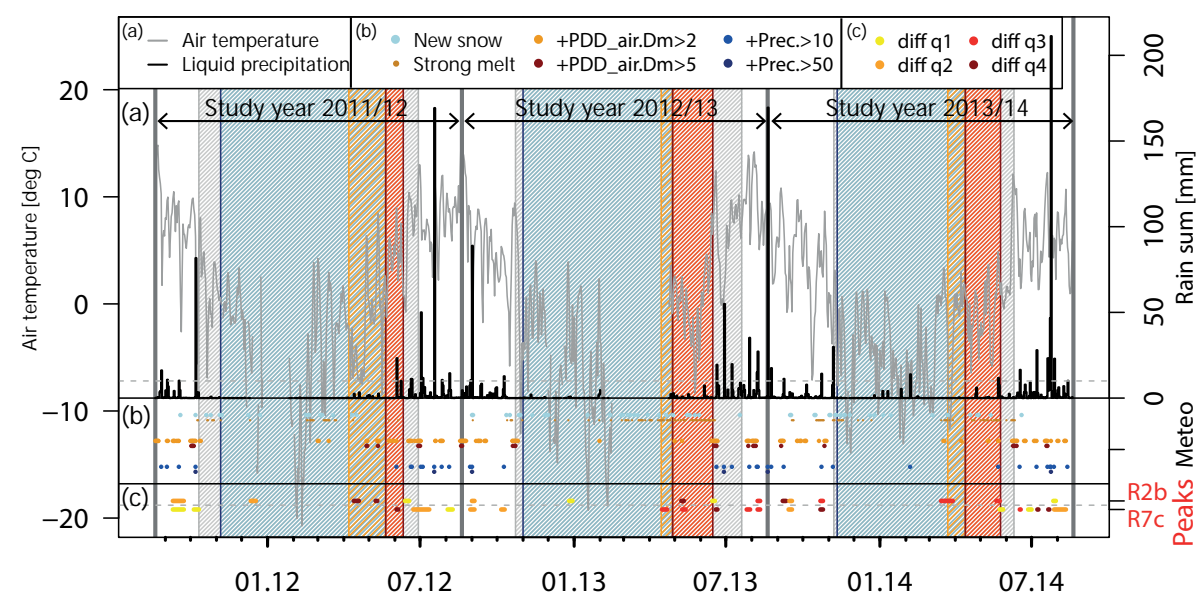

Figure 7. Comparison of velocity peaks at R2b and R7c to meteorological factors. Panel (a): air temperature and liquid precipitation, both measured at the weather station within the study. Vertical grey lines separate the 3 different years of observation (2011/12, 2012/13, 2013/14). Panel (b): in the middle of the plots, the coloured dots refer to the occurrence of exceptional values of meteorological factors: new snow on this day fresh snow was clearly visible on webcam images; strong melt - on this day strong melt was clearly visible on webcam images; $+\mathrm{PDD}_{\text {air }} \cdot \mathrm{Dm} \geq 2$ - the difference of $\mathrm{PDD}_{\text {air }}$ on that day compared to the monthly mean of $\mathrm{PDD}_{\text {air }}$ was above $2{ }^{\circ} \mathrm{C} ;+\mathrm{PDD}_{\text {air }} \cdot \mathrm{Dm} \geq 5-$ the difference of $\mathrm{PDD}_{\text {air }}$ on that day compared to the monthly mean of $\mathrm{PDD}_{\text {air }}$ was above $5{ }^{\circ} \mathrm{C}$; + Prec $\geq 10-$ the daily amount of liquid precipitation was $10 \mathrm{~mm}$ or more; + Prec $\geq 50$ - the daily amount of liquid precipitation was $50 \mathrm{~mm}$ or more. Panel (c): occurrence of velocity peaks for R2b (upper bars) and R7c (lower bars). The colours of the peak periods refer to the strength of the peaks (given as the 25, 50, and $75 \%$ quantile of $\operatorname{diff}_{\mathrm{p}}$ ).

\subsection{Intra-annual variability: velocity peaks}

In addition to the seasonal variations in velocities, short peaks in velocity of a few days' duration can be observed at some GPS stations. Applying the methods described in Sect. 3.4, velocity peaks were detected for the lower station on rock glacier Breithorn (R2b), and the two fast-moving stations on rock glaciers Dirru R7a and R7c (Figs. 4, 6, and 7). However, at R7a only one peak was detected during the zero curtain period in 2012/13 (11-23 June 2013, $\left.\operatorname{diff}_{p}=8 \%\right)$. We therefore limited the analysis of peaks to stations $\mathrm{R} 2 \mathrm{~b}$ and R7c.

\subsubsection{Characteristics of velocity peaks}

In total, 17 peaks were detected for R2b and 20 for R7c (Tables 5 and 7). The velocity periods detected as peaks at the two stations occurred roughly around the same time of the year; for example, in every year and at both stations one or more peaks were detected during the zero curtain period. Eight of these peaks, observed at R2b and R7c were synchronous, or at least overlapping. In addition, one peak at R7c started directly after a peak at R2b. Nevertheless, most of the individual peaks (R2b: $N=10$; R7c: $N=13$ ) did not occur simultaneously at both stations, and sometimes strong peaks were detected at one station but not at the other station (e.g. 9-11 May 2012 at R2b; Fig. 7).

Peaks were detected between March and December and most frequently between May and October $(N=32)$. For R7c, the number of peaks per month was highest for June $(N=5)$ and July $(N=4)$. For R2b, most peaks occurred in September $(N=4)$ and May $(N=3)$. The duration of the peaks for R2b ranged from 3 to 15 days (with a median (md) of 4 days) and from 1 day to 20 days for $\mathrm{R} 7 \mathrm{c}(\mathrm{md}=5)$. The number of peaks per individual study year varied between 5 
and 7 for R2b and 5 and 8 for R7c (Table 5). At both stations, most peaks occurred in 2013/14 (R2b: $N=7$; R7c: $N=8$ ). At R7c, during each year, and for R2b in 2012/13 and 2013/14, the number of peaks was higher during the snow-free than the snow cover or zero curtain period (Table 5). Even if the number of peaks is normalized by the duration of the periods, most peaks occurred during the snowfree period (except in 2011/12 at R7c). At R2b, in 2011/12 the number of peaks was highest during the snow cover period.

The strength of the peaks ( $\operatorname{diff}_{\mathrm{p}}$ ) was stronger at R7c (with a mean $\mu_{\text {diff }}=237 \%$ and a median $\operatorname{md}_{\text {diff }}=47 \%$ ) than at $\mathrm{R} 2 \mathrm{~b}\left(\mu_{\text {diff }_{\mathrm{p}}}=20 \%, \mathrm{md}_{\text {diff }_{\mathrm{p}}}=11 \%\right.$; Table 7$)$. At R7c, diff ranged from 7 to $2424 \%$ and at R2b from 6 to $98 \%$. At R2b, the mean of $\operatorname{diff}_{\mathrm{p}}$ was highest in $2011 / 12\left(\mu_{\text {diff }_{\mathrm{p}}}=38 \%\right)$ and lowest in $2013 / 14\left(\mu_{\text {diff }}=11 \%\right)$. At R7c, the mean of $\operatorname{diff}_{\mathrm{p}}$ was highest in 2013/14 (mean=484\%) and lowest in 2012/13 (mean $=68 \%$ ). On average over all peaks, the median of $\operatorname{diff}_{\mathrm{p}}$ was highest for peaks during the zero curtain period at both stations (Table 5). The mean strength of the peaks, however, was on average stronger over all peaks for R2b stronger for the snow cover $\left(\mu_{\text {diff }_{\mathrm{p}}}=38 \%\right)$ than for the zero curtain ( $\mu_{\text {diff }_{\mathrm{p}}}=21 \%$ ) or snow-free period $\left(\mu_{\text {diff }}=10 \%\right)$. At R7c, generally the mean of $\operatorname{diff}_{\mathrm{p}}$ was stronger during the snowfree $\left(\mu_{\text {diff }_{\mathrm{p}}}=268 \%\right)$ than the snow cover period $\left(\mu_{\text {diff }_{\mathrm{p}}}=\right.$ $113 \%$ ), but no peaks occurred during the snow cover period outside the zero curtain period. For both stations, the weakest peaks per period occurred during the snow-free period (Table 5). At R7c, in 2012/13 and in 2013/14 the strongest peaks also occurred during the snow-free period, whereas in 2011/12 the strongest peak at R7c occurred during the zero curtain period. At R2b, the strongest peak in 2011/12 occurred during the snow cover, in 2012/13 during the zero curtain, and in 2013/14 during the snow-free period. The average strength of the peaks (median of $\operatorname{diff}_{\mathrm{p}}$ ) was highest during the zero curtain period at R2b in 2012/13 and 2013/14 and at $\mathrm{R} 7 \mathrm{c}$ in 2011/12 and 2013/14 (Table 5). In 2011/12 at R2b the average strength (median) was highest during the snow cover period, and at R7c in 2013/14 it was highest during the snow-free period.

The cumulative horizontal displacement during peaks was equal to $10 \%(2.1 \mathrm{~m}, 99$ days) of the total displacement for R2b and $25 \%$ (3.6 m, 124 days) for R7c. For R2b, around $10 \%\left(6.8^{\circ}\right)$ of the total inclination occurred during peaks. For R7c, inclination was generally smaller, but inclinometer measurements at R7c were not available for the whole period. At R2b, the displacement during the strongest peak $\left(\right.$ diff $_{\mathrm{p}}=98 \%$ ), which lasted for 3 days, was $9 \mathrm{~cm}$. During this peak, the mast at R2b tilted by $2.5^{\circ}$ and the elevation changed by $11 \mathrm{~cm}$. However, the change in elevation corrected for the mast tilt was only $1 \mathrm{~cm}$. At $\mathrm{R} 7 \mathrm{c}$, the displacement during the strongest peak $\left(\operatorname{diff}_{\mathrm{p}}=2424 \%\right)$, lasting for 1 day, was $49 \mathrm{~cm}$ and the change in elevation was $26 \mathrm{~cm}$.

The deviation from the main movement direction ( $\left.\operatorname{diff}_{\mathrm{azi}}\right)$ was in general small but stronger during peak periods (R2b: $\mu_{\text {diff }_{\text {azi }}}=17^{\circ} ;$ R7c: $\left.\mu_{\text {diff }_{\text {azi }}}=10^{\circ}\right)$ than during no-peak periods (R2b: $\mu_{\text {diff }_{\text {azi }}}=6^{\circ} ; \mathrm{R} 7 \mathrm{c}: \mu_{\text {diff }_{\mathrm{azi}}}=4^{\circ}$ ), especially for R2b (Fig. 4). During the strongest peaks, diff azi was $27^{\circ}$ for $\mathrm{R} 7 \mathrm{c}$ and $123^{\circ}$ for R2b (towards its orographic right margin). The strong diff azi during the strongest peak points to a rotation of the station (around the $Z$ axis that could not be detected with the measurement set-up). However, excluding the strongest peak at $\mathrm{R} 2 \mathrm{~b}$, the mean of $\operatorname{diff}_{\mathrm{azi}}$ of all peak periods $\left(\mu_{\text {diff }_{\text {azi }}}=3^{\circ}\right)$ becomes even smaller than for all no-peak periods $\left(\mu_{\text {diff }_{\text {azi }}}=6^{\circ}\right)$. For R7c, excluding the strongest peak has nearly no influence of the mean of $\operatorname{diff}_{\mathrm{azi}}$ of peak periods $\left(\mu_{\text {diff }_{\mathrm{azi}}}=10^{\circ}\right)$.

\subsubsection{Relation to meteorological factors}

During the snow-free periods, 10 peaks are detected for $\mathrm{R} 2 \mathrm{~b}$ and 16 for $\mathrm{R} 7 \mathrm{c}(N=26$; Table 5$)$. For most of these peaks, strong liquid precipitation $(\geq 10 \mathrm{~mm})$ was measured during the peak $(N=19)$ and/or a few days before the peak $(N=$ 23, Fig. 7, Table 7). Two peaks where liquid precipitation during or shortly before the peak was below $10 \mathrm{~mm}$ occurred during a period (in June) when part of the study area was still snow covered. Furthermore, during most of the peaks where precipitation during the peak was below $10 \mathrm{~mm}$ new snow that melted again within a few days $(N=4)$ was observed, in combination with a rain on snow event (ROS). Only for one peak (at R7c, 27 June-1 July 2014) was precipitation below $10 \mathrm{~mm}$, and no new snow was observed. During this peak a few remaining snow patches from winter snow cover were visible on webcam images and the cumulative amount of precipitation was $9 \mathrm{~mm}$, indicating ROS. During several days $(N=6)$ on which the daily amount of precipitation was high ( $\geq 10 \mathrm{~mm}$ ), no peak was observed (Fig. 7).

The positive relationship between the occurrence of a peak during the snow-free period and the maximum of the daily amount of precipitation during the peak is also visible in spineplots (e.g. Fig. 8 and Figs. S2 and S3 in the Supplement). However, when precipitation was exceptionally high (maximum daily amount $\geq 40 \mathrm{~mm}$ ), a peak was not always detected (Fig. 7). In addition, for both stations the number of peaks was higher when new snow was observed during or 7 days before the peak (see, e.g., Fig. 8), but few no-peak periods occurred when new snow was detected.

During the snow cover period $(N=11)$, six peaks occurred during the zero curtain period, in combination with an ROS (Fig. 7 and Table 7). The five peaks outside the zero curtain period all occurred at $\mathrm{R} 2 \mathrm{~b}$ and can either be related to new snow and strong melt $(N=3)$, $\operatorname{ROS}(N=1)$, or to a combination of these $(N=1 \text {; Fig. } 7 \text { and Table } 7)^{3}$. However, except for two peaks (in December 2011 and December 2012), all peaks during the snow cover period occurred dur-

\footnotetext{
${ }^{3}$ During two peaks no meteo data were available, but during those peaks new snow and strong melt were visible on webcam images.
} 

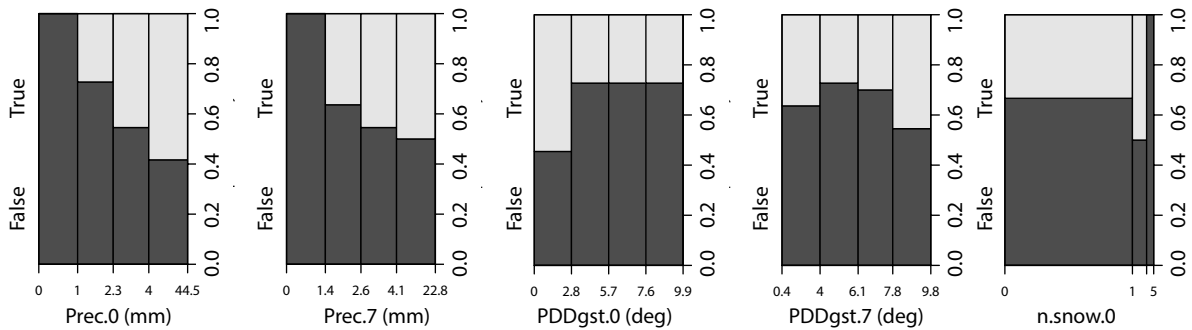

Figure 8. Spineplots for periods during the snow-free period of R7c for selected variables (see Table 3) showing frequencies of the occurrence of a peak (light grey) as opposed to the absence (dark grey) of a peak conditional in relation to potential explanatory variables. Bar widths refer to the $25 \%$ quantiles of the explanatory variables, except for new snow (n.snow). Note: spineplots for all potential explanatory variables of both positions (R2b and R7c) during the snow cover and snow-free period can be found in the Supplement to this paper (Figs. S2 and S3).

(a)
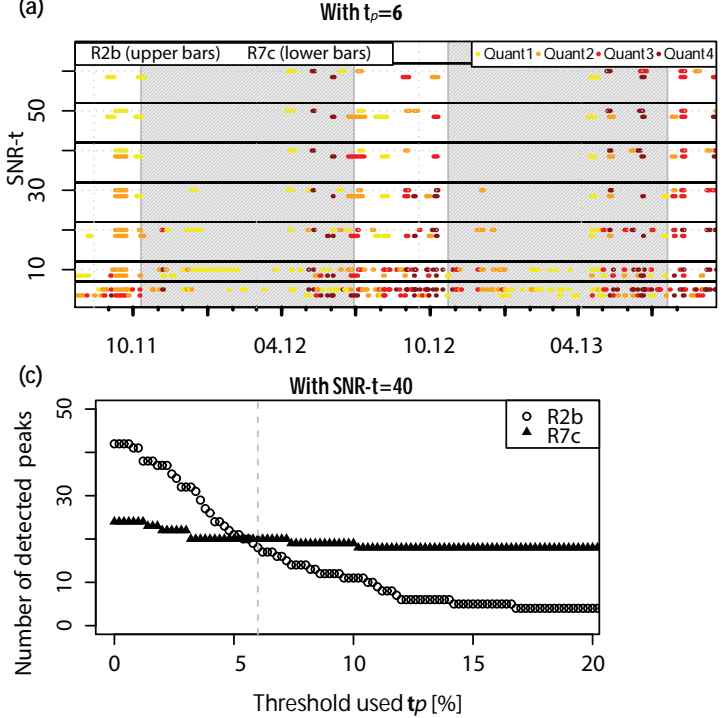

(b)

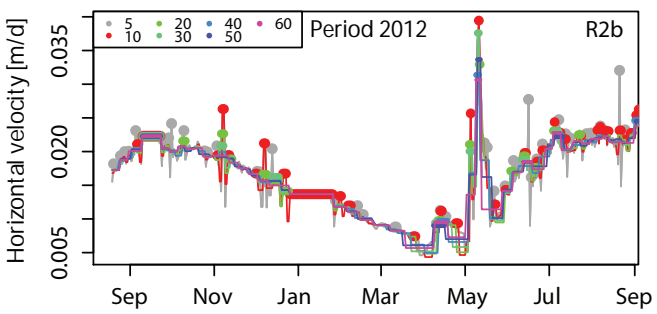

With $\mathrm{t}_{p}=6$

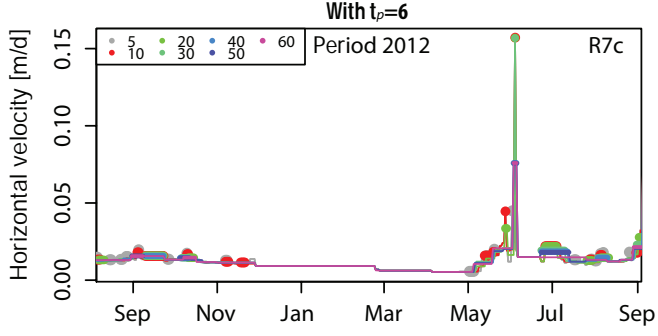

Figure 9. Detected peaks depend on the chosen SNR threshold (SNR-t) for velocity estimations and threshold $\left(t_{\mathrm{p}}\right)$ for peak detection. Panel (a): sensitivity of detected peaks for different SNR-t $\left(t_{\mathrm{p}}=6 \%\right)$ for R2b and R7c. The colours refer to the strength of the peak (diff $\mathrm{p}$; the 25 , 50 , and $75 \%$ quantile of diff ). The period with an insulating winter snow cover is shadowed in light grey. Panel (b): estimated horizontal velocities and detected peaks (points) applying different SNR-t for R2b (upper) and R7c (lower). Panel (c): sensitivity of the detected peaks for thresholds $t_{\mathrm{p}}$ for R2b (points) and R7c (triangles). The $x$ axis refers to different values applied for $t_{\mathrm{p}}$. In this study, we apply $t_{\mathrm{p}}=6$ and $\mathrm{SNR}-\mathrm{t}=40$.

ing a period when a zero curtain could be detected within the study site at least for one station. For both stations, during the snow cover period a positive relationship between the number of days during zero curtain or increasing PDD $_{\text {air }}$ during the peak and the number of peaks exists (see, e.g., Figs. S2 and S3). In addition, for R7b, the number of peaks increases with mean and maximum amount of precipitation during the peak.

Based on those observations and the $P$ values of the Wilcoxon rank-sum test (Table S1 in the Supplement), the potential variables for the full logistic regression models were as follows: mean and maximum amount of precipitation, $\mathrm{PDD}_{\mathrm{gst}}$, and $\mathrm{PDD}_{\text {air }}$ (during as well as 7 days before the peak) and the indices for snow cover (snow.ind) and zero curtain (zc.ind).
The AUROC values of the final models $(N=16$; see, e.g., Table 6) ranged from 0.69 to 0.85 . Hence, according to Hosmer et al. (2013), these models were fair to good. Although different variables for precipitation and temperature were included in the models, the estimates for precipitation and temperature were similar. The highest AUROC was obtained if liquid precipitation and $\mathrm{PDD}_{\mathrm{gst}}$ during the peak were included in the full model (Table 6). An overview of all final logistic regression models, the variables included, and the AUROC values is given in Table $\mathrm{S} 2$.

All the final models included the variables' precipitation and position. While precipitation was significant in most of the final models $(N=14)$, position was only significant in one of the final models. Additionally, final models mostly contained the interaction terms of precipitation with snow 


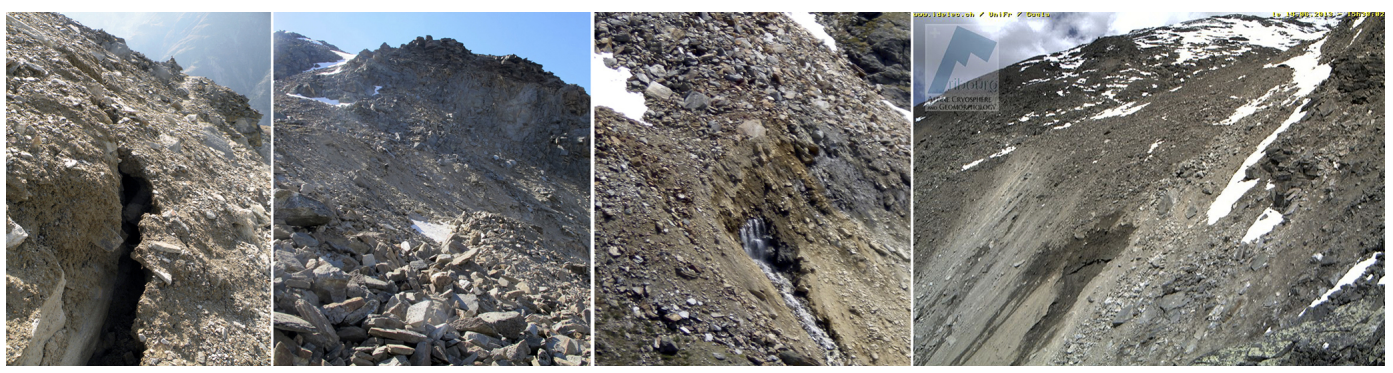

Figure 10. Visible cracks (left, from September 2011) and depressions (middle left, from June 2013) at the front of the rock glacier Breithorn, visible water outflow (middle right) at the front of rock glacier Dirru (from June 2013), and a webcam image of the front of rock glacier Breithorn (right, from 14 June 2013).

Table 6. Model coefficients (and standard errors in parentheses) of the final model with highest AUROC values (final model 1) and the final model with highest AUROC without temperature (final model 2). In addition, the corresponding AUROC and AIC values are given. An overview of all variables and their meaning is given in Table 3. In addition, an index with the GPS position (R2b or R7c) is applied for potential differences between the two rock glaciers.

\begin{tabular}{lrr}
\hline & final model 1 & final model 2 \\
\hline (Intercept) & $-0.06(0.70)$ & $-1.27(0.36)^{\mathrm{c}}$ \\
Prec.0 & $1.80(0.44)^{\mathrm{c}}$ & $0.74(0.24)^{\mathrm{b}}$ \\
PDD $_{\text {gst. }}$ & $-0.21(0.10)^{\mathrm{a}}$ & \\
zc.ind $^{\mathrm{a}}$ & $2.58(1.29)^{\mathrm{a}}$ & \\
snow.ind & $-3.02(1.34)^{\mathrm{a}}$ & \\
posR2b & $-0.69(0.47)$ & $-0.83(0.47)$ \\
Prec.0:PDD gst.0 & $-0.20(0.05)^{\mathrm{c}}$ & \\
Prec.0:zc.ind & $1.18(0.38)^{\mathrm{b}}$ & \\
Prec.0:snow.ind & $-1.85(0.44)^{\mathrm{c}}$ & \\
Prec.0:posR2b & & $-0.73(0.24)^{\mathrm{b}}$ \\
AUROC & 0.85 & 0.75 \\
AIC & 148.5 & 168.53 \\
\hline
\end{tabular}

Significance of Wald test: ${ }^{\mathrm{a}}<0.05,{ }^{\mathrm{b}}<0.01 ;^{\mathrm{c}}<0.001$.

cover $(N=13)$, with position $(N=11)$, with zero curtain $(N=11)$, and/or with temperature $(N=9)$. Temperature was included in 11 of the final models but was only significant in 1 final model.

The coefficients of the final models indicate the following (values refers to the final model with the highest AUROC; Table 6): chances of the occurrence of a peak are generally higher during the snow-free period than during winter conditions and higher for R7c than for R2b (a reduction of the odds for R2b of approximately 0.2 ). Zero curtain has the strongest influence on odds; during zero curtain the odds for the occurrence of a peak increase by more than 14 times, but uncertainties are large (Table 6). The estimates for precipitation were mostly higher for the mean than the maximum amount of precipitation and generally higher if only the days during the peak were included. In all final models the influence of precipitation on the odds is higher during the snow-free than the snow cover period and stronger for R7c than for R2b. For example, during the snow-free period, an increase in $\log$ (Prec.0) by one unit leads to an increase in the odds by a factor of 6 for R7c and a factor of 3 for R2b. A change in temperature (by $1^{\circ} \mathrm{C}$ ) generally has a smaller influence on the odds than a change in precipitation by one unit.

\section{Discussion}

The following discussion has three distinct elements. Firstly, we set out the methodological strengths and weaknesses of our approach (Sect. 5.1). The second and third parts of our discussion focus on the research questions set out at the beginning of the paper: thus, we explore how the observed main patterns of short-term variability in this study compare with observations from previous studies (Sect. 5.2) and discuss potential controlling factors and the related processes (Sect. 5.3).

\subsection{Advantages and limitations of our approach}

The observed intra-annual variability strongly depends on the temporal resolution of the velocity estimations. In comparison to most previous studies, our data have a much higher temporal resolution (Table 1; see, e.g., Haeberli, 1985; Perruchoud and Delaloye, 2007). Furthermore, in comparison to the small number of earlier studies with similarly high temporal resolution (daily), our measurements have (a) a much longer temporal coverage and (b) better spatial coverage due to the inclusion of three neighbouring rock glaciers (earlier studies with high temporal resolution only included 13 point measurements on a single rock glacier; Roer, 2005; Krainer and He, 2006; Buchli et al., 2013; Table 1). This paper extends the data described in Wirz et al. (2015) with an additional year's worth of observations.

A key advantage of the SNRT method is that the smoothing windows directly depend on the SNR of the data (Wirz et al., 2014). This, however, means that the temporal resolution of velocity estimations may differ between individual stations. Where velocities are lower, the velocity periods (smoothing windows) need to be larger to get an SNR above 
Table 7. Detected peaks. Main characteristics, including duration of peak (Dur.), the velocity (Vel.), diff , during the period of winter snow cover (snow) and during zero curtain (zc) are given. In addition, supposed main triggers are given: f.snow - fresh snow that melts again within a few days; rain.p - intense $(>10 \mathrm{~mm})$ liquid precipitation during the peak-period; rain.bp - intense liquid precipitation before the peak (within $\leq 7$ days before the start of the peak-period); high.T - high temperature in summer; melt - strong snowmelt in winter or spring; ROS - rain on snow event.

\begin{tabular}{|c|c|c|c|c|c|c|c|c|c|c|c|c|c|}
\hline Pos. & From & To & Dur. & Vel. & $\operatorname{Diff}_{\mathrm{p}}$ & Snow & $\mathrm{zc}$ & f.snow & rain.p & rain.bp & high.T & Melt & ROS \\
\hline $\mathrm{R} 7 \mathrm{c}$ & 10 September 2011 & 23 September 2011 & 14 & 0.02 & 10 & $\mathrm{~F}$ & $\mathrm{~F}$ & $\mathrm{x}$ & $\mathrm{x}$ & & & & $\mathrm{x}$ \\
\hline $\mathrm{R} 2 \mathrm{~b}$ & 10 September 2011 & 23 September 2011 & 14 & 0.02 & 11 & $\mathrm{~F}$ & $\mathrm{~F}$ & $\mathrm{x}$ & $\mathrm{x}$ & & & & $\mathrm{x}$ \\
\hline $\mathrm{R} 7 \mathrm{c}$ & 5 October 2011 & 11 October 2011 & 7 & 0.01 & 7 & $\mathrm{~F}$ & $\mathrm{~F}$ & $\mathrm{x}$ & $\mathrm{x}$ & & & & \\
\hline $\mathrm{R} 2 \mathrm{~b}$ & 12 December 2011 & 18 December 2011 & 7 & 0.02 & 9 & $\mathrm{~T}$ & $\mathrm{~F}$ & $\mathrm{x}$ & & & & $\mathrm{x}$ & \\
\hline $\mathrm{R} 2 \mathrm{~b}$ & 13 April 2012 & 19 April 2012 & 7 & 0.01 & 65 & $\mathrm{~T}$ & $\mathrm{~F}$ & $\mathrm{x}$ & & & & $\mathrm{x}$ & $\mathrm{x}$ \\
\hline $\mathrm{R} 2 \mathrm{~b}$ & 9 May 2012 & 11 May 2012 & 3 & 0.03 & 98 & $\mathrm{~T}$ & $\mathrm{~F}$ & $\mathrm{x}$ & & & & $\mathrm{x}$ & $(\mathrm{x})$ \\
\hline $\mathrm{R} 7 \mathrm{c}$ & 3 June 2012 & 5 June 2012 & 3 & 0.08 & 314 & $\mathrm{~T}$ & $\mathrm{~T}$ & & & & & $\mathrm{x}$ & (x) \\
\hline $\mathrm{R} 2 \mathrm{~b}$ & 13 June 2012 & 18 June 2012 & 6 & 0.02 & 7 & $\mathrm{~F}$ & $\mathrm{~F}$ & & & & & $\mathrm{x}$ & $(\mathrm{x})$ \\
\hline $\mathrm{R} 7 \mathrm{c}$ & 23 June 2012 & 12 July 2012 & 20 & 0.02 & 37 & $\mathrm{~F}$ & $\mathrm{~F}$ & & $\mathrm{x}$ & & $\mathrm{x}$ & & \\
\hline $\mathrm{R} 7 \mathrm{c}$ & 3 August 2012 & 9 August 2012 & 7 & 0.01 & 21 & $\mathrm{~F}$ & $\mathrm{~F}$ & & $\mathrm{x}$ & & & & \\
\hline $\mathrm{R} 7 \mathrm{c}$ & 30 August 2012 & 4 September 2012 & 6 & 0.02 & 37 & $\mathrm{~F}$ & $\mathrm{~F}$ & $\mathrm{x}$ & $\mathrm{x}$ & & & & \\
\hline $\mathrm{R} 2 \mathrm{~b}$ & 1 September 2012 & 4 September 2012 & 4 & 0.02 & 11 & $\mathrm{~F}$ & $\mathrm{~F}$ & $\mathrm{x}$ & $\mathrm{x}$ & & & & \\
\hline $\mathrm{R} 7 \mathrm{c}$ & 6 October 2012 & 10 October 2012 & 5 & 0.02 & 46 & $\mathrm{~F}$ & $\mathrm{~F}$ & & $\mathrm{x}$ & $\mathrm{x}$ & & & \\
\hline $\mathrm{R} 2 \mathrm{~b}$ & 26 December 2012 & 30 December 2012 & 5 & 0.02 & 7 & $\mathrm{~T}$ & $\mathrm{~F}$ & & & & & $\mathrm{x}$ & $\mathrm{x}$ \\
\hline $\mathrm{R} 7 \mathrm{c}$ & 16 April 2013 & 22 April 2013 & 7 & 0.01 & 52 & $\mathrm{~T}$ & $\mathrm{~T}$ & $\mathrm{x}$ & & & & $\mathrm{x}$ & \\
\hline $\mathrm{R} 2 \mathrm{~b}$ & 9 May 2013 & 12 May 2013 & 4 & 0.03 & 30 & $\mathrm{~T}$ & $\mathrm{~T}$ & & & & & $\mathrm{x}$ & $\mathrm{x}$ \\
\hline $\mathrm{R} 7 \mathrm{c}$ & 10 May 2013 & 14 May 2013 & 5 & 0.02 & 50 & $\mathrm{~T}$ & $\mathrm{~T}$ & & & & & $\mathrm{x}$ & $\mathrm{x}$ \\
\hline $\mathrm{R} 2 \mathrm{~b}$ & 15 June 2013 & 18 June 2013 & 4 & 0.03 & 6 & $\mathrm{~F}$ & $\mathrm{~F}$ & & & & & $\mathrm{x}$ & $(\mathrm{x})$ \\
\hline $\mathrm{R} 7 \mathrm{c}$ & 19 June 2013 & 21 June 2013 & 3 & 0.04 & 155 & $\mathrm{~F}$ & $\mathrm{~F}$ & & & & & $\mathrm{x}$ & $\mathrm{x}$ \\
\hline $\mathrm{R} 7 \mathrm{c}$ & 26 July 2013 & 30 July 2013 & 5 & 0.02 & 49 & $\mathrm{~F}$ & $\mathrm{~F}$ & & $\mathrm{x}$ & & & & \\
\hline $\mathrm{R} 7 \mathrm{c}$ & 8 August 2013 & 11 August 2013 & 4 & 0.02 & 90 & $\mathrm{~F}$ & $\mathrm{~F}$ & & $\mathrm{x}$ & $\mathrm{x}$ & & & \\
\hline $\mathrm{R} 2 \mathrm{~b}$ & 8 August 2013 & 11 August 2013 & 4 & 0.03 & 14 & $\mathrm{~F}$ & $\mathrm{~F}$ & & $\mathrm{x}$ & & & & \\
\hline $\mathrm{R} 2 \mathrm{~b}$ & 7 September 2013 & 11 September 2013 & 5 & 0.03 & 17 & $\mathrm{~F}$ & $\mathrm{~F}$ & & $\mathrm{x}$ & & & & \\
\hline $\mathrm{R} 7 \mathrm{c}$ & 14 September 2013 & 18 September 2013 & 5 & 0.02 & 46 & $\mathrm{~F}$ & $\mathrm{~F}$ & $\mathrm{x}$ & & & & & $\mathrm{x}$ \\
\hline $\mathrm{R} 2 \mathrm{~b}$ & 15 September 2013 & 18 September 2013 & 4 & 0.03 & 10 & $\mathrm{~F}$ & $\mathrm{~F}$ & $\mathrm{x}$ & & & & & $\mathrm{x}$ \\
\hline $\mathrm{R} 7 \mathrm{c}$ & 22 October 2013 & 25 October 2013 & 4 & 0.03 & 125 & $\mathrm{~F}$ & $\mathrm{~F}$ & $(\mathrm{x})$ & & & & & $\mathrm{x}$ \\
\hline $\mathrm{R} 2 \mathrm{~b}$ & 22 October 2013 & 25 October 2013 & 4 & 0.03 & 11 & $\mathrm{~F}$ & $\mathrm{~F}$ & (x) & & & & & $\mathrm{x}$ \\
\hline $\mathrm{R} 2 \mathrm{~b}$ & 15 March 2014 & 29 March 2014 & 15 & 0.01 & 12 & $\mathrm{~T}$ & $\mathrm{~F}$ & $\mathrm{x}$ & & & & $\mathrm{x}$ & \\
\hline $\mathrm{R} 2 \mathrm{~b}$ & 20 May 2014 & 24 May 2014 & 5 & 0.02 & 12 & $\mathrm{~T}$ & $\mathrm{~T}$ & & & & & $\mathrm{x}$ & $\mathrm{x}$ \\
\hline $\mathrm{R} 7 \mathrm{c}$ & 24 May 2014 & 28 May 2014 & 5 & 0.03 & 33 & $\mathrm{~T}$ & $\mathrm{~T}$ & & & & & $\mathrm{x}$ & $\mathrm{x}$ \\
\hline $\mathrm{R} 7 \mathrm{c}$ & 17 June 2014 & 18 June 2014 & 2 & 0.06 & 102 & $\mathrm{~F}$ & $\mathrm{~F}$ & & $\mathrm{x}$ & & & & $\mathrm{x}$ \\
\hline $\mathrm{R} 7 \mathrm{c}$ & 27 June 2014 & 1 July 2014 & 5 & 0.03 & 22 & $\mathrm{~F}$ & $\mathrm{~F}$ & & $(\mathrm{x})$ & & & & $\mathrm{x}$ \\
\hline $\mathrm{R} 7 \mathrm{c}$ & 8 July 2014 & 8 July 2014 & 1 & 0.49 & 2424 & $\mathrm{~F}$ & $\mathrm{~F}$ & $\mathrm{x}$ & & & & & \\
\hline $\mathrm{R} 7 \mathrm{c}$ & 21 July 2014 & 21 July 2014 & 1 & 0.27 & 1075 & $\mathrm{~F}$ & $\mathrm{~F}$ & $\mathrm{x}$ & & & & & \\
\hline $\mathrm{R} 2 \mathrm{~b}$ & 27 July 2014 & 30 July 2014 & 4 & 0.03 & 7 & $\mathrm{~F}$ & $\mathrm{~F}$ & & $\mathrm{x}$ & (x) & & & \\
\hline $\mathrm{R} 7 \mathrm{c}$ & 28 July 2014 & 11 August 2014 & 15 & 0.03 & 41 & $\mathrm{~F}$ & $\mathrm{~F}$ & & $\mathrm{x}$ & $\mathrm{x}$ & & & \\
\hline $\mathrm{R} 2 \mathrm{~b}$ & 11 August 2014 & 14 August 2014 & 4 & 0.03 & 8 & $\mathrm{~F}$ & $\mathrm{~F}$ & & $\mathrm{x}$ & & & & \\
\hline
\end{tabular}

SNR-t. For the relatively slow stations R6a and R6b, with an average duration of the velocity periods of 1 month for R6a and 2 months for R6b, the temporal resolutions of velocities are similar to most previous studies on intra-annual variability in rock glaciers (e.g. Perruchoud and Delaloye, 2007; Liu et al., 2013). However, for the other stations, velocity estimations presented in this study have a much higher temporal resolution (ranging from a few days to 2 weeks). The temporal resolution of the position measurements is similar to those in Buchli et al. (2013) and Krainer and He (2006), but the temporal coverage in these studies was less than 1 year and thus periods with similar seasonal conditions occurred only once.
A main limitation of our data is that we have few point measurements on individual landforms at the surface, which are (a) not necessarily representative of the entire landform, or parts of it (e.g. rock glacier tongue) and (b) a result of the cumulative displacement potentially occurring at different depths (Fig. 1). However, surface velocity measurements with a high spatial resolution have shown that the velocity field is comparatively homogenous (at least along the central flow line; see, e.g., Kääb et al., 2003). Furthermore, remotesensing data show that movement extends across the whole active lobe of Dirru (R7a and R7c, Strozzi et al., 2009a) and Breithorn (R2a and R2b Strozzi et al., 2009b). In addition, surface velocity measurements form a good approximation 
of the movement at depth (Lambiel and Delaloye, 2004), as the main movement within a rock glacier is concentrated within (few) thin shear horizons (see, e.g., Arenson et al., 2002).

Nevertheless, movement observed at the surface may occur at different depths (Fig. 1, cf. Roer et al., 2008), and thus, observed displacement at the surface may result from (1) a displacement within one (Arenson et al., 2002) or more shear horizons (Delaloye et al., 2013), (2) internal deformation above the shear horizon(s) (this is mostly small however; Arenson et al., 2002), (3) displacement within or at the base of the active layer (Buchli et al., 2013), (4) sliding of the front similar to a rotational slide (Roer et al., 2008); and/or (5) displacement or rotation of a single boulder (Wirz et al., 2014).

\subsection{Short-term variability in velocities in the context of previous research}

The observed patterns of the short-term variability in the rock glaciers within this study area generally correspond well with observations in earlier studies.

The observed increase in mean annual velocities over the 3 years and at all stations is in good agreement with the observed average increase in velocities of $+32 \%$ from summer 2012 to summer 2014 observed at eight rock glaciers in the Valais and Bernese Alps by the Swiss permafrost monitoring network (PERMOS, 2015). In these earlier studies, the observed long-term acceleration seems, with a phase lag of 1 year, to correlate with an increase in MAGST (see, e.g., Hoelzle et al., 1998; Delaloye et al., 2010; PERMOS, 2013). However, our data set is too small to allow conclusions to be drawn on variation on multi-annual timescales but provides further indications that winter temperatures and short-term melt periods may be influential with regard to mean annual velocities.

Observed intra-annual patterns on the rock glaciers within this study area are similar to observations made in previous studies on intra-annual variability (Table 1): the seasonal cycle and the timing of minima and maxima in velocity observed in this study agree well with previous observations on rock glaciers (Table 1; Haeberli, 1985; Roer, 2005; Kääb et al., 2005; Perruchoud and Delaloye, 2007; Buchli et al., 2013), although differences between individual rock glaciers and from year to year have been reported (Delaloye et al., 2010). Similarly, as described by Haeberli (1985), the maximum in velocity occurred earlier at the lower station than at the upper station on the same rock glacier (Fig. 3).

Compared to most earlier studies, the higher temporal resolution of our measurements (for most of the stations) allows us to detect more detail in the intra-annual variability in rock glacier velocities, such as the timing of seasonal acceleration, the asymmetric seasonal cycle, and the velocity peaks. In previous studies, a deceleration in winter was also observed to be smoother than acceleration in spring (Table 1, see, e.g., Perruchoud and Delaloye, 2007). However, as for the stations on the rock glacier Steintälli, such an asymmetric annual cycle was not always detected in previous studies (e.g. on Muragl rock glacier: Arenson et al., 2002; Kääb, 2005; Krainer and He, 2006). Both the rock glacier Muragl and Steintälli have low velocities of less than $0.5 \mathrm{ma}^{-1}$, and hence, the lack of an asymmetric annual cycle may result from a coarser temporal resolution of velocity estimations ( monthly; Sect. 4.1).

Previously, short abrupt velocity peaks in rock glacier velocities were only detected on one rapidly moving rock glacier in a nearby valley during snowmelt (Furggwanghorn rock glacier with MAV $>3 \mathrm{ma}^{-1}$ : Buchli et al., 2013). However, in most former studies, temporal resolution was too low to be able to detect such short-lived velocity peaks. The coarser temporal resolution of the velocity estimations (median duration of $\geq 15 \mathrm{~d}$, Sect. 5.1) might also explain why for rock glacier Steintälli (R6a, R6b) and at the upper stations of the rock glacier Breithorn (R2a) and Dirru (R7a) almost no such peaks, lasting only a few days, were detected.

\subsection{Effects of meteorological factors on short-term velocity variations and hypotheses on underlying processes}

In the following we discuss factors identified from our analysis and link these to potential processes driving the observed temporal patterns of rock glacier movements. In doing so we focus on intra-annual and short-term variations. Since both velocities and meteorological factors are based on surface measurements, while movement and related processes also occur at depth, it is necessary to make an inference from our surface point measurements to the behaviour of the complete landform. In linking velocity's response to meteorological forcing, we use lag times as one potential indicator for understanding and determining processes occurring at depth.

Based on the observations of this study we hypothesize that peaks in velocities were mainly caused by strong water infiltration from heavy precipitation or strong snowmelt during or a few days before the peak.

Velocity peaks were only detected at the two fast-moving rock glacier tongues (R2b and R7c). Most probably, the lack of detection of velocity peaks at the other stations is the result of the coarser temporal resolution of the velocity estimates ( $\geq 2$ weeks) compared to the resolution at R2b and R7c (5 days, applying SNRT with SNR-t $=40$ ).

All of the velocity peaks detected at R2b and R7c occurred outside cold winter conditions and during or shortly after high water input, driven by heavy precipitation, snowmelt (indicated by ROS or positive temperatures during the snow cover period; cf. Marks et al., 2001), or late summer snowfall 
melting rapidly within a few days (Fig. 7). Both qualitative and statistical analyses show that the influence of temperature is weaker and indicate that likely no peak was solely caused by high temperatures without associated water input.

Water infiltration from heavy precipitation or snowmelt may lead to an increase in pore water pressure and hence a reduction in shear resistance (Terzaghi, 1943), thus triggering increased velocities. In addition, water infiltration can lead to a rapid warming of the ground at depth (through thermal advection and release of latent heat; Rist and Phillips, 2005), in turn leading to an increase in the strain rates of the ice in the frozen matrix (see, e.g., Yamamoto, 2013) and a higher unfrozen water content (especially if temperatures were close to $0^{\circ} \mathrm{C}$; Anderson et al., 1973; Arenson et al., 2002); both factors facilitate slope movement.

At both stations, maximum velocities at $\mathrm{R} 2 \mathrm{~b}$ and $\mathrm{R} 7 \mathrm{~b}$ within 1 year were mostly observed during peaks that occurred during the zero curtain period in combination with rain on snow. Similarly, at the Furggwanghorn rock glacier, two velocity peaks were observed during the snowmelt period which were suggested to be caused by snow meltwater that filtered in through the active layer, ran off along the permafrost table, and, thus, reduced the shear resistance in this zone (Buchli et al., 2013). The short duration of the peaks further suggests that the water that has filtered in runs off within a short time. Indeed, the few existing studies on the hydrology of rock glaciers have all shown that water is transmitted through the rock glacier within a few hours (Krainer and Mostler, 2002; Ikeda et al., 2008; Buchli et al., 2013). They further observed that water flows in direct contact with the ice (Krainer et al., 2007), which might indicate ground ice acting as a flow barrier. Furthermore, the observed short time lag between the water input (e.g. precipitation) and the start of the velocity peak indicates that the water that had filtered in reached the shear horizon(s) within a short time and/or that the corresponding shear horizon lies at rather shallow depths (e.g. at the active layer base; Buchli et al., 2013). The velocity peaks at the Furggwanghorn rock glacier were caused by a displacement at the active layer base (at $4 \mathrm{~m}$ depth; Buchli et al., 2013). However, as in this study only measurements at the surface are available, it is unknown where the measured movement actually took place and if the water that had filtered in reached the corresponding shear horizon (Fig. 1).

Only approximately half of the peaks occurred simultaneously at the two stations, more frequently during the snowfree period. In addition, velocity peaks were not always detected after or during strong precipitation events or rain on snow events during the zero curtain period, and no clear reasons were found why no velocity peak occurred in these cases. One potential explanation for these observations, especially during the snowmelt period, might be that the amount of water infiltration caused by snowmelt can vary significantly even within a catchment (Grünewald et al., 2010). The timing and intensity of heavy rain in summer can also vary significantly even within a small catchment (see, e.g.,
Goodrich et al., 1995). Indeed, the measured precipitation during single rain fall events in summer 2014 sometimes varied significantly between the two weather stations within the study site. These observations, however, also indicate that the exact circumstances causing a velocity peak are still largely unknown.

Furthermore, differences in the development of the drainage system within the rock glacier may explain the variable response to similar forcing events. Speed-up events of short duration are a well-known phenomenon for glaciers and are generally assumed to result from high water input into a poorly connected drainage system and to terminate as soon as the drainage system becomes more channelized and more efficient (Kamb, 1987; Nienow et al., 1998). Two observations indicate in our case that at least a partly channelized drainage system existed before the velocities started to increase: (a) the location of the water outflow visible at the front of rock glacier Dirru during periods of strong melt (see, e.g., Fig. 10), and hence the location of related drainage channels, remained more or less constant in its position over the 3 years; (b) the spring outflow at the front of Dirru always became visible before (or at the same time as) velocities started to accelerate.

Regarding water infiltration, high velocities in combination with steep topography may lead to a positive feedback through the opening of fissures and depressions, as has been observed in this study (Fig. 10) and elsewhere (e.g. Roer et al., 2008; Delaloye et al., 2013; Buchli et al., 2013), and to more open pore spaces (dilatancy effect). This could enhance permeability of the ground and favour fast water infiltration and hence lead to further acceleration in velocities.

\section{The findings of this study suggest that rock glaciers have a seasonal cycle in velocities, with sea- sonal acceleration apparently strongly influenced by meltwater and the amount of seasonal deceler- ation influenced by winter temperatures.}

Seasonal decrease in velocity was typically smooth and occurred with a phase lag of a few weeks to months behind decreasing air temperature and GST (Fig. 3). The smooth deceleration in winter may, beside a phase-lagged cooling through heat conduction, be the result of a decrease in water content within a rock glacier (and shear horizon in particular) as a result of strongly reduced water input (percolation) during winter conditions (nearly no liquid precipitation or snowmelt that might lead to drainage; Coe et al., 2003); it may also be influenced by slow refreezing of pore water as a result of heat loss (see, e.g., Ikeda et al., 2008). The observation that both observed minimum temperatures and minimum velocities in winter increased over the 3 study years provides further support for the suggestion that winter temperatures influence deceleration of rock glacier movements in winter, as previously proposed by various authors (Ikeda et al., 2008; Kääb et al., 2007; Delaloye et al., 2010). Commonly, higher GSTs in winter are associated with a thicker 
insulating snow cover (see, e.g., Ikeda et al., 2008). This scenario, however, is unlikely for this study as at the MeteoSwiss station in Grächen, the thickest winter snow cover (mean in January and February) occurred in 2012.

In contrast to the smooth deceleration in winter, an abrupt and strong acceleration in spring was observed at most stations; this commenced during snowmelt periods (zero curtain) and was typically related to short-term speed-up events. These observations indicate that in contrast to winter deceleration, acceleration in spring is strongly influenced by water infiltration (from snowmelt) as previously indicated (see, e.g., Krummenacher et al., 2008; Ikeda et al., 2008; Buchli et al., 2013). As a rock glacier body is likely to be permeable (see, e.g., Arenson et al., 2002), it seems plausible that during the snowmelt period water infiltration also occurs in the frozen body beneath the active layer and thus reaches greater depths and potentially the shear horizon (see, e.g., Fig. 1). Dilatancy effects during dry winter conditions might additionally lead to the formation of open pore spaces, which in spring might act as preferential flow paths (Ikeda et al., 2008). Immediate water infiltration to depth might further explain why, in spring, the differences between the individual stations in the start of the acceleration were generally smaller compared to the differences in the start of deceleration, which is likely governed by slow heat conduction.

\section{Conclusions and further work}

Within this study, continuous GPS measurements on three rock glaciers with distinct morphology from summer 2011 to summer 2014 have been analysed in relation to meteorological factors, such as GST, air temperature, precipitation, and snow(melt). The presented data set is unique regarding the high temporal resolution of the measurements (daily) in combination with the comparably long temporal ( 3 years) and spatial coverage (six stations on three independent rock glaciers). The high temporal resolution (daily) of the data allows us to investigate the influence of meteorological factors, and their changes, on the short-term variability in rock glacier movement. We performed detailed qualitative and statistical analyses on the intra-annual variability in rock glacier movement, with a clear focus on the short-term peaks, and its relation to meteorological factors. The main findings of this study are as follows:

- At two steep and fast-moving rock glacier tongues in addition to the seasonal cycle, short velocity peaks occurred immediately after strong water input from snowmelt (in combination with ROS) and heavy precipitation. This rapid and high-magnitude response in rock glacier surface velocities suggests high water input events with rapid infiltration into the rock glacier body as a forcing mechanism.

- The seasonal variability in the rock glacier movement is strongly influenced by snow meltwater infiltration and winter temperatures, as indicated by the observation that both velocities (minimal velocities in winter and MAV) and winter temperatures increased over the observation period and that spring acceleration is mostly rapid and abrupt (peaks) and always started during the snowmelt period.

Our measurements, and the statistical analyses, revealed that there are large similarities but also clear differences in the reaction to changes in environmental factors and the resulting short-term variability, both between different rock glaciers but also different parts (e.g. tongue vs. middle) of the same landform.

The high resolution and spatial proximity of GPS and meteorological measurements allowed us to study and demonstrate the influence of meteorological factors on the shortterm variability in the movements for three different rock glaciers. However, it is likely that the surface movement on rock glaciers derives from movements occurring at different depths, which would require subsurface measurements.

\section{Data availability}

All data discussed in this study have been collected in a central database and are publicly accessible at http://data. permasense.ch.

\section{The Supplement related to this article is available online at doi:10.5194/esurf-4-103-2016-supplement.}

Author contributions. Measurement design, installations, and maintenance: J. Beutel, S. Gruber, and V. Wirz; study concept: V. Wirz, S. Gruber, R. Purves, and J. Beutel; analyses: V. Wirz in collaboration with S. Gubler, S. Gruber, and R. Purves; interpretation of results: V. Wirz, A. Vieli, I. Gärtner-Roer, S. Gruber, and R. Purves; manuscript: V. Wirz wrote the paper, J. Beutel, I. Gärtner-Roer, S. Gruber, R. Purves, and A. Vieli edited and commented on the manuscript.

Acknowledgements. This project (as part of the project X-Sense 1 and X-sense 2) was scientifically evaluated by the SNSF, financed by the Swiss Confederation, and funded by Nano-Tera.ch and by the faculty of science of the University of Zurich. This work was also aided by the Grid Computing Competence Center (GC3, www.gc3.uzh.ch) with computational infrastructure and assistance, including customized libraries (gc_gps and GC3Pie) and user support. We thank R. Delaloye (Physical Geography at the University of Fribourg) for fruitful discussions and for providing webcam images. This study would not have been possible without the collaboration with colleagues from the project $X$-Sense, notably B. Buchli (Computer Engineering and Networks Lab of ETH Zurich), who contributed significantly to the design of the 
GPS stations, P. Limpach (Geodesy and Geodynamics Lab of ETH Zurich), who processed the daily GPS solutions; S. Weber and T. Gsell (Computer Engineering and Networks Lab of ETH Zurich), who contributed significantly to the installation and maintenance of the field site; and H. Raetzo (Federal Office for the Environment), who provided valuable insights and discussion concerning placement of GPS stations. The software iAssist (Keller et al., 2010) was used to program and read out the iButtons.

Edited by: M. Krautblatter

\section{References}

Anderson, D., Tice, A., and McKim, H.: The unfrozen water and the apparent specific heat capacity of frozen soils, in: Proceedings of the Second International Conference on Permafrost, 13-28 July 1973, Washington, DC, USA, 289-295, 1973.

Arenson, L., Hoelzle, M., and Springman, S.: Borehole deformation measurements and internal structure of some rock glaciers in Switzerland, Permafrost Periglac., 13, 117-135, doi:10.1002/ppp.414, 2002.

Barsch, D.: Nature and importance of mass-wasting by rock glaciers in alpine permafrost environments, Earth Surf. Proc. Land., 2, 231-245, doi:10.1002/esp.3290020213, 1977.

Barsch, D.: Permafrost creep and rock glaciers, Permafrost Periglac., 3, 175-188, doi:10.1002/ppp.561, 1992.

Barsch, D. and Hell, G.: Photogrammetrische Bewegungsmessungen am Blockgletscher Murtèl I, Oberengadin, Schweizer Alpen, Zeitschrift für Gletscherkunde und Glazialgeologie, 11, 111142, 1975.

Baur, F.: Constructing confidence sets using rank statistics, J. Am. Stat. Assoc., 67, 687-690, 1972.

Bernknopf, R. L., Campbell, R. H., Brookshire, D. S., and Shapiro, C. D.: A probabilistic approach to landslide hazard mapping in Cincinnati, Ohio, with applications for economic evaluation, Bulletin of the Association of Engineering Geologists, 25, 39-56, 1988.

Beutel, J., Buchli, B., Ferrari, F., Keller, M., Thiele, L., and Zimmerling, M.: X-Sense: sensing in extreme environments, in: Proceedings of Design, Automation and Test in Europe, 2011, 1-6, IEEE, Grenoble, France, 1460-1465, 2011.

Boeckli, L., Brenning, A., Gruber, S., and Noetzli, J.: Permafrost distribution in the European Alps: calculation and evaluation of an index map and summary statistics, The Cryosphere, 6, 807820, doi:10.5194/tc-6-807-2012, 2012.

Brenning, A. and Trombotto, D.: Logistic regression modeling of rock glacier and glacier distribution: topographic and climatic controls in the semi-arid Andes, Geomorphology, 81, 141-154, doi:10.1016/j.geomorph.2006.04.003, 2006.

Buchli, B., Sutton, F., and Beutel, J.: GPS-equipped wireless sensor network node for high-accuracy positioning applications, in: Wireless Sensor Networks, Springer, Trento, Italy, 179-195, 2012.

Buchli, T., Merz, K., Zhou, X., Kinzelbach, W., and Springman, S.: Characterization and monitoring of the Furggwanghorn rock glacier, Turtmann valley, Switzerland: results from 2010 to 2012, Vadose Zone J., 12, 1-15, doi:10.2136/vzj2012.0067, 2013.

Can, T., Nefeslioglu, H., Gokceoglu, C., Sonmez, H., and Duman, T.: Susceptibility assessments of shallow earth- flows triggered by heavy rainfall at three catchments by logistic regression analyses, Geomorphology, 72, 250-271, doi:10.1016/j.geomorph.2005.05.011, 2005.

Coe, J., Ellis, W., Godt, J., Savage, W., Savage, J., Michael, J., Kibler, J., Powers, P., Lidke, D., and Debray, S.: Seasonal movement of the Slumgullion landslide determined from Global Positioning System surveys and field instrumentation, Eng. Geol., 68, 67-101, doi:10.1016/S0013-7952(02)00199-0, 2003.

Dach, R., Hugentobler, U., Fridez, P., and Meindl, M.: Bernese GPS Software, Version 5.0, Astronomical Institute, University of Bern, Bern, Switzerland, 2007.

Delaloye, R., Kaufmann, M., Bodin, X., Hausmann, H., Ikeda, A., Kääb, A., Kellerer-Pirklbauer, A., Krainer, K., Lambiel, C., Mihajlovic, D., Roer, I., and Thibert, E.: Recent interannual variations of rock glacier creep in the European Alps, in: Proceedings of the 9th International Conference on Permafrost, 28 June3 July 2008, Fairbanks, Alaska, USA, 343-348, 2008 a.

Delaloye, R., Strozzi, T., Lambiel, C., Perruchoud, E., and Raetzo, H.: Landslide-like development of rock glaciers detected with ERS-1/2 SAR interferometry, in: Proceedings of the 8th International Conference on Permafrost, 21-25 July 2003, Zurich, Switzerland, 26-30, 2008b.

Delaloye, R., Lambiel, C., and Gärtner-Roer, I.: Overview of rock glacier kinematics research in the Swiss Alps, Geogr. Helv., 65, 135-145, doi:10.5194/gh-65-135-2010, 2010.

Delaloye, R., Barboux, C., Morard, S., Abbet, D., and Gruber, V.: Rapidly moving rock glaciers in Mattertal, in: Mattertal - ein Tal in Bewegung, Publikation zur Jahrestagung der Schweizerischen Geomorphologischen Gesellschaft, St. Niklaus, Switzerland, 2131, 2013.

Francou, B. and Reynaud, L.: 10 year surficial velocities on a rock glacier (Laurichard, French Alps), Permafrost Periglac., 3, 209 213, doi:10.1002/ppp.3430030306, 1992.

Friendly, M.: Mosaic displays for multi-way contingency tables, J. Am. Stat. Assoc., 89, 190-200, 1994.

Goodrich, D., Faurres, J., Woolhiser, D., Lane, L., and Sorooshian, S.: Measurement and analysis of small-scale convective storm rainfall variability, J. Hydrol., 173, 283-308, doi:10.1016/0022-1694(95)02703-R, 1995.

Graf, C., Deubelbeiss, Y., Bühler, Y., Meier, L., McArdell, B., Christen, M., and Bartelt, P.: Gefahrenkartierung Mattertal: Grundlagenbeschaffung und numerische Modellierung von Murgängen, in: Mattertal - ein Tal in Bewegung, Publikation zur Jahrestagung der Schweizerischen Geomorphologischen Gesellschaft, St. Niklaus, Switzerland, vol. 29, 85-112, 2013.

Grünewald, T., Schirmer, M., Mott, R., and Lehning, M.: Spatial and temporal variability of snow depth and ablation rates in a small mountain catchment, The Cryosphere, 4, 215-225, doi:10.5194/tc-4-215-2010, 2010.

Gubler, S., Fiddes, J., Keller, M., and Gruber, S.: Scaledependent measurement and analysis of ground surface temperature variability in alpine terrain, The Cryosphere, 5, 431-443, doi:10.5194/tc-5-431-2011, 2011.

Haeberli, W.: Creep of mountain permafrost: internal structure and flow of alpine rock glaciers, Mit. Ver. Was., 77, 5-142, 1985.

Haeberli, W., Hoelzle, M., Kääb, A., Keller, F., Vonder Mühll, D., and Wagner, S.: Ten years after drilling through the permafrost of the active rock glacier Murtèl, Eastern Swiss Alps: answered questions and new perspectives, in: Proceedings of the 7th In- 
ternational Conference on Permafrost, 23-27 June, Nordicana, Yellowknife, Canada, 403-410, 1998.

Haeberli, W., Hallet, B., Arenson, L., Elconin, R., Humlum, O., Kääb, A., Kaufmann, V., Ladanyi, B., Matsuoka, N., Springman, S., and Vonder Mühll, D.: Permafrost creep and rock glacier dynamics, Permafrost Periglac., 17, 189-214, doi:10.1002/ppp.561, 2006.

Hausmann, H., Krainer, K., Brückl, E., and Mostler, W.: Creep of two Alpine rock glaciers - observation and modelling (Ötztaland Stubai Alps, Austria), Grazer Schriften der Geographie und Raumforschung, 43, 145-150, 2007.

Hoelzle, M., Wagner, S., Kääb, A., and Vonder Mühll, D.: Surface movement and internal deformation of ice-rock mixtures within rock glaciers at Pontresina-Schafberg, Upper Engadin, Switzerland, in: Proceedings of the Seventh International Conference on Permafrost, 23-27 June 1998, Yellowknife, Northwest Territories, Canada, 465-471, 1998.

Hosmer, J., David, W., Lemeshow, S., and Sturdivant, R.: Applied Logistic Regression, 3rd edn., John Wiley and Sons, New York, USA, 2013.

Humlum, O., Christiansen, H., and Juliussen, H.: Avalanchederived rock glaciers in Svalbard, Permafrost Periglac., 18, 7588, doi:10.1002/ppp.580, 2007.

Ikeda, A., Matsuoka, N., and Kääb, A.: Fast deformation of perennially frozen debris in a warm rock-glacier in the Swiss Alps: an effect of liquid water, J. Geophys. Res., 113, 1-12, doi:10.1029/2007JF000859, 2008.

Johnson, J. and Nickling, W.: Englacial temperature and deformation of a rock glacier in the Kluane Range, Yukon Territory, Canada, Can. J. Earth Sci., 16, 2275-2283, 1979.

Jomelli, V., Delval, C., Grancher, D., Escande, S., Brunstein, D., Hetu, B., Filion, L., and Pech, P.: Probabilistic analysis of recent snow avalanche activity and weather in the French Alps, Cold Reg. Sci. Technol., 47, 180-192, doi:10.1016/j.coldregions.2006.08.003, 2007.

Kääb, A.: Remote Sensing of Mountain Glaciers and Permafrost Creep, vol. 48, Schriftenreihe Physische Geographie, Department of Geography, University of Zurich, Zurich, Switzerland, 2005.

Kääb, A., Kaufmann, V., Ladstädter, R., and Eiken, T.: Rock glacier dynamics: implications from high-resolution measurements of surface velocity fields, in: Proceedings of the 8th International Conference on Permafrost, 21-25 July 2003, Zurich, Switzerland, 501-506, 2003.

Kääb, A., and Weber, M.: Development of transverse ridges on rock glaciers: field measurements and laboratory experiments, Permafrost Periglac., 15, 379-391, doi:10.1002/ppp.506, 2004.

Kääb, A., Huggel, C., Fischer, L., Guex, S., Paul, F., Roer, I., Salzmann, N., Schlaefli, S., Schmutz, K., Schneider, D., Strozzi, T., and Weidmann, Y.: Remote sensing of glacier- and permafrostrelated hazards in high mountains: an overview, Nat. Hazards Earth Syst. Sci., 5, 527-554, doi:10.5194/nhess-5-527-2005, 2005.

Kääb, A., Frauenfelder, R., and Roer, I.: On the response of rock glacier creep to surface temperature increase, Global Planet. Change, 56, 172-187, doi:10.1016/j.gloplacha.2006.07.005, 2007.
Kamb, B.: Glacier surge mechanism based on linked cavity configuration of the basal water conduit system, J. Geophys. Res.-Solid, 92, 9083-9100, doi:10.1029/JB092iB09p09083, 1987.

Kaufmann, V., and Ladstädter, R.: Mapping of the 3D surface motion field of Doesen rock glacier (Ankogel Group, Austria) and its spatio-temporal change (1954-1998) by means of digital photogrammetry, in: Proceedings ot the 9th International Symposium on High Mountain Remoste Sensing Cartography (HMRSC-IX), Graz, 14-15 September 2006, Grazer Schriften der Geographie und Raumforschung, 43, 134-144, 2007.

Keller, M., Hungerbuehler, G., Knecht, O., Sheikh, S., Beutel, J., Gubler, S., Fiddes, J., and Gruber, S.: iAssist: rapid deployment and maintenance of tiny sensing systems, in: Proceedings of the 8th ACM Conference on Embedded Networked Sensor Systems, SenSys '10, 3-5 November 2010, 401-402, ACM, New York, USA, doi:10.1145/1869983.1870043, 2010.

Konrad, S., Humphrey, N., Steig, E., Clark, D. J. P., and Pfeffer, W.: Rock glacier dynamics and paleoclimatic implications, Geology, 27, 1131-1134, doi:10.1130/00917613(1999)027<1131:RGDAPI>2.3.CO;2, 1999.

Krainer, K. and He, X.: Flow velocities of active rock glaciers in the Austrian Alps, Geogr. Ann. A, 88, 267-280, doi:10.1111/j.04353676.2006.00300.x, 2006.

Krainer, K. and Mostler, W.: Hydrology of active rock glaciers: examples from the Austrian Alps, Arct. Antarct. Alp. Res., 142149, 2002.

Krainer, K., Mostler, W., and Spötl, C.: Discharge from active rock glaciers, Austrian Alps: a stable isotope approach, Aust. J. Earth Sci., 100, 102-112, 2007.

Krummenacher, B., Mihajlovic, D., Nussbaum, A., and Staub, B.: 20 Jahre Furggentälti, Permafrostuntersuchungen auf der Gemmi, Geographica Bernensia G80, Geographisches Institut der Universität Bern, Bern, Switzerland, 2008.

Labhart, T.: Geologie der Schweiz, 3rd edn., Ott Verlag, Thun, Switzerland, 1995.

Lambiel, C. and Delaloye, R.: Contribution of real-time kinematic GPS in the study of creeping mountain permafrost: examples from the Western Swiss Alps, Permafrost Periglac., 15, 229-241, doi:10.1002/ppp.496, 2004.

Lambiel, C., Delaloye, R., and Perruchoud, E.: Yearly and seasonally variations of surface velocities on creeping permafrost bodies. Cases studies in the Valais Alps, in: 3rd Swiss Geoscience Meeting, Zürich, 18-19 November 2005, 1-2, 2005.

Laube, P. and Purves, R. S.: How fast is a cow? Cross-scale analysis of movement data, Transactions in GIS, 15, 401-418, doi:10.1111/j.1467-9671.2011.01256.x, 2011.

Limpach, P. and Grimm, D.: Rock glacier monitoring with low-cost GPS receivers, in: Abstract Volume 7th Swiss Geoscience Meeting, 20-21 November 2009, Neuchatel, Switzerland, 247-248, 2009.

Liu, L., Millar, C. I., Westfall, R. D., and Zebker, H. A.: Surface motion of active rock glaciers in the Sierra Nevada, California, USA: inventory and a case study using InSAR, The Cryosphere, 7, 1109-1119, doi:10.5194/tc-7-1109-2013, 2013.

Lugon, R., Delaloye, R., and Perruchoud, E.: Aléas naturels en zone de pergélisol et détection des Alpes valaisannes, Suisse, Rapport final, Programme INTERREG IIIa France-Suisse Haut-Rhône, Institut universitaire Kurt Bösch, Sion, Suisse; Géosciences, Institut de Géographie, Université de Fribourg, Suisse, 2008. 
Marks, D., Link, T., Winstral, A., and Garen, D.: Simulating snowmelt processes during rain-on-snow over a semi-arid mountain basin, Ann. Glaciol., 32, 195-202, doi:10.3189/172756401781819751, 2001.

Mihajlovic, D., Kölbing, D., Kunz, I., Schwab, S., Kienholz, H., Budmiger, K., Imhof, M., and Krummenacher, B.: Developing new methods for monitoring periglacial phenomena, in: Proceedings of the 8th International Conference on Permafrost, 2125 July 2003, Zurich, Switzerland, 765-770, 2003.

Nienow, P., Sharp, M., and Willis, I.: Seasonal changes in the morphology of the subglacial drainage system, Haut Glacier d'Arolla, Switzerland, Earth Surf. Proc. Land., 23, 825843, doi:10.1002/(SICI)1096-9837(199809)23:9<825::AIDESP893>3.0.CO;2-2, 1998.

Ohlmacher, G. C. and Davis, J. C.: Using multiple logistic regression and GIS technology to predict landslide hazard in northeast Kansas, USA, Eng. Geol., 69, 331-343, doi:10.1016/S00137952(03)00069-3, 2003.

Outcalt, S., Nelson, F., and Hinkel, K.: The zero-curtain effect: heat and mass transfer across an isothermal region in freezing soil, Water Resour. Res., 26, 1509-1516, doi:10.1029/WR026i007p01509, 1990.

PERMOS: Permafrost in Switzerland 2008/2009 and 2009/2010, edited by: Noetzli, J., Glaciological Report (Permafrost) No. 10/11 of the Cryospheric Commission of the Swiss Academy of Sciences, Zurich, Switzerland, 2013.

PERMOS: Key messages on permafrost in Switzerland 2013/2014, unpublished report by the PERMOS Scientific Committee, Zurich, Switzerland, 7 pp., 2015.

Perruchoud, E. and Delaloye, R.: Short-term changes in surface velocities on the Becs-de-Bosson rock glacier (western Swiss Alps), Grazer Schriften der Geographie und Raumforschung, 43, 131-136, 2007.

Potter, N.: Ice-cored rock glacier, Galena Creek, northern Absaroka Mountains, Wyoming, Geol. Soc. Am. Bull., 83, 3025-3058, doi:10.1130/0016-7606(1972)83[3025:IRGGCN]2.0.CO;2, 1972.

Rist, A. and Phillips, M.: First results of investigations on hydrothermal processes within the active layer above alpine permafrost in steep terrain, Norsk Geogr. Tidsskr., 59, 177-183, doi:10.1080/00291950510020574, 2005.

Robin, X., Turck, N., Hainard, A., Tiberti, N., Lisacek, F., Sanchez, J., and Müller, M.: pROC: an open-source package for $\mathrm{R}$ and $\mathrm{S}+$ to analyse and compare ROC curves, BMC Bioinformatics, 12, 1-8, doi:10.1186/1471-2105-12-77, 2011.

Roer, I.: rock glacier Kinematics in a High Mountain Geosystem, $\mathrm{Ph} . \mathrm{D}$. thesis, Mathematisch-Naturwissenschaftlichen Fakultät der Rheinischen Friedrich-Wilhelms-Universität Bonn, Bonn, Germany, 2005.

Roer, I., Kääb, A., and Dikau, R.: rock glacier acceleration in the Turtmann valley (Swiss Alps): probable controls, Norsk Geogr. Tidsskr., 59, 157-163, doi:10.1080/00291950510020655, 2005.

Roer, I., Haeberli, W., Avian, M., Kaufmann, V., Delaloye, R., Lambiel, C., and Kääb, A.: Observations and considerations on destabilizing active rock glaciers in the European Alps, in: Proceedings of the 9th International Conference on Permafrost, 28 June3 July 2008, Fairbanks, Alaska, USA, vol. 2, 1505-1510, 2008.

Schmid, M.-O., Gubler, S., Fiddes, J., and Gruber, S.: Inferring snowpack ripening and melt-out from distributed measurements of near-surface ground temperatures, The Cryosphere, 6, 11271139, doi:10.5194/tc-6-1127-2012, 2012.

Schoeneich, P., Bodin, X., Echelard, T., Kaufmann, V., KellererPirklbauer, A., Krysiecki, J., Lieb, G.: Velocity changes of rock glaciers and induced hazards, Engineering Geology for Society and Territory, 1, 223-227, doi:, 2015.

Sloan, V. and Dyke, L.: Decadal and millennial velocities of rock glaciers, Selwyn Mountains, Canada, Geogr. Ann. A, 80, 237 249, 1998.

Strozzi, T., Delaloye, R., Raetzo, H., and Wegmüller, U.: RADAR interferometric observations of destabilized rock glaciers, in: Proceedings of the "Fringe 2009 Workshop", 30 November4 December 2009, Frascati, Italy, (ESA SP-677, March 2010), $1-5,2009$ a.

Strozzi, T., Wegmuller, U., Werner, C., Wiesmann, A., Delaloye, R., and Raetzo, H.: Survey of landslide activity and rock glaciers movement in the Swiss Alps with TerraSAR-X, in: Geoscience and Remote Sensing Symposium, 2009 IEEE International, IGARSS, 12-17 July 2009, vol. 3, pp. III-53-III-56, doi:10.1109/IGARSS.2009.5418175, 2009b.

Terzaghi, K.: Theoretical Soil Mechanics, Wiley, New York, USA, 510 pp., 1943.

Venables, W. and Ripley, B.: Modern Applied Statistics with S, 4th edn., ISBN 0-387-95457-0, Springer, New York, USA, 2002.

Vitek, J. and Giardino, J.: Rock glaciers, in: Rock Glaciers: A Review of the Knowledge Base, edited by: Vitek, J. and Giardino, J., Allen and Unwin Boston, London, UK, 1-26, 1987.

Vonder Mühll, D.: Evidence of intrapermafrost groundwater flow beneath an active rock glacier in the Swiss Alps, Permafrost Periglac., 3, 169-173, doi:10.1002/ppp.3430030216, 1992.

Wagner, S.: Creep of alpine permafrost, investigated on the Murtèl rock glacier (short communication), Permafrost Periglac., 3, 157-162, doi:10.1002/ppp.3430030214, 1992.

Wagner, S.: Dreidimensionale Modellierung zweier Gletscher und Deformationsanalyse von eisreichem Permafrost, Mit. Ver. Was., 1-146, doi:10.3929/ethz-a-000954695, 1994.

Wahrhaftig, C. and Cox, A.: Rock glaciers in the Alaska Range, Geol. Soc. Am. Bull., 70, 383-436, doi:10.1130/00167606(1959)70[383:RGITAR]2.0.CO;2, 1959.

Wirz, V., Limpach, P., Buchli, B., Beutel, J., and Gruber, S.: Temporal characteristics of different cryosphere-related slope movements in high mountains, in: Landslide Science and Practice, Springer, Berlin, Heidelberg, Germany, 383-390, 2013.

Wirz, V., Beutel, J., Gruber, S., Gubler, S., and Purves, R. S.: Estimating velocity from noisy GPS data for investigating the temporal variability of slope movements, Nat. Hazards Earth Syst. Sci., 14, 2503-2520, doi:10.5194/nhess-14-2503-2014, 2014.

Wirz, V., Marten Geertsema, M., Gruber, S., and Purves, R.: Temporal variability of diverse mountain permafrost slope movements derived from multi-year daily GPS data, Mattertal, Switzerland, Landslides, 1-17, doi:10.1007/s10346-014-0544-3, 2015.

$\mathrm{Xu}$, W., Yu, W., and Zhang, G.: Prediction method of debris flow by logistic model with two types of rainfall: a case study in the Sichuan, China, Nat. Hazards, 62, 733-744, doi:10.1007/s11069-011-9988-0, 2012.

Yamamoto, Y.: Instabilities in Alpine permafrost: strength and stiffness in a warming regime, $\mathrm{Ph}$. D. thesis, Institut for Geotechnical Engeneering, ETH Zurich, Zurich, Switzerland, 2013. 